\title{
Targeting the GPR119/incretin axis: a promising new therapy for metabolic-associated fatty liver disease
}

Jianan Zhao' ${ }^{1}$ Yu Zhao ${ }^{1,3,4}$, Yiyang $\mathrm{Hu}^{2,3,4^{*}}$ and Jinghua Peng ${ }^{1,3,4^{*}}$ (0)

*Correspondence:

yyhuliver@163.com; pengjinghua2004@163.com

${ }^{1}$ Institute of Liver Diseases, Shuguang Hospital Affiliated

To Shanghai, University of Traditional Chinese Medicine, 528, Zhangheng Road, Shanghai, China

2 Institute of Clinical

Pharmacology, Shuguang Hospital Affiliated To

Shanghai, University of Traditional Chinese Medicine, 528, Zhangheng Road, Shanghai, China

Full list of author information is available at the end of the article

\begin{abstract}
In the past decade, G protein-coupled receptors have emerged as drug targets, and their physiological and pathological effects have been extensively studied. Among these receptors, GPR119 is expressed in multiple organs, including the liver. It can be activated by a variety of endogenous and exogenous ligands. After GPR119 is activated, the cell secretes a variety of incretins, including glucagon-like peptide-1 and glucagonlike peptide-2, which may attenuate the metabolic dysfunction associated with fatty liver disease, including improving glucose and lipid metabolism, inhibiting inflammation, reducing appetite, and regulating the intestinal microbial system. GPR119 has been a potential therapeutic target for diabetes mellitus type 2 for many years, but its role in metabolic dysfunction associated fatty liver disease deserves further attention. In this review, we discuss relevant research and current progress in the physiology and pharmacology of the GPR119/incretin axis and speculate on the potential therapeutic role of this axis in metabolic dysfunction associated with fatty liver disease, which provides guidance for transforming experimental research into clinical applications.
\end{abstract}

Keywords: GPCR, GPR119, Incretins, Metabolic (dysfunction)-associated fatty liver disease, Liver disease

\section{Introduction}

Metabolic (dysfunction)-associated fatty liver disease (MAFLD) has become a major health problem in developed countries. It has become the first pandemic liver disease in China, and its prevalence rate is ballooning. It is a genetic stress disorder related to the environment and to obesity, hypertension, hyperlipidemia, and type 2 diabetes [1]. The lifestyle of patients with MAFLD has a direct effect on disease development; for example, host microbial environment disorders and endocrine and metabolic environment disorders driven by poor diet and exercise habits are important factors in the development of MAFLD. Currently, MAFLD is highly heterogeneous; thus, categorizing all patients with a diverse and differential array of disease drivers as patients with non-alcoholic fatty liver disease (NAFLD) can negatively impact clinical decision making. Therefore, NAFLD has been renamed as MAFLD [2-7], and MAFLD

(C) The Author(s) 2021. This article is licensed under a Creative Commons Attribution 4.0 International License, which permits use, sharing, adaptation, distribution and reproduction in any medium or format, as long as you give appropriate credit to the original author(s) and the source, provide a link to the Creative Commons licence, and indicate if changes were made. The images or other third party material in this article are included in the article's Creative Commons licence, unless indicated otherwise in a credit line to the material. If material is not included in the article's Creative Commons licence and your intended use is not permitted by statutory regulation or exceeds the permitted use, you will need to obtain permission directly from the copyright holder. To view a copy of this licence, visit http://creativecommons. org/licenses/by/4.0/. 
is used instead of NAFLD in this article. The latest diagnostic criteria for MAFLD are based on histology (biopsy sample), imaging or blood biomarker evidence of fat accumulation in the liver (hepatic steatosis) with one of the following three criteria: overweight/obesity, diagnosis of type 2 diabetes mellitus (T2DM), or evidence of metabolic dysregulation [8-10]. Most drugs currently on the market are focused on weight and diet control, but they may produce side effects; for example, pioglitazone may cause weight gain. In addition, orlistat has no significant effect on liver fibrosis, and surgical procedures may be traumatic. Therefore, more effective and safer medications are needed [11, 12].

The G protein-coupled receptor (GPCR) superfamily has many extensively studied members [13, 14]. GPR119 is a member of the GPCR superfamily. GPR119 activation has ligand-dependent dual effects: pancreatic secretion of insulin in a glucosedependent manner and intestinal secretion of incretins (glucagon-like peptide-1 [GLP-1] and glucose-dependent insulinotropic peptide [GIP]) [15]. In addition, many studies have shown that the activation of GPR119 causes an increase in intracellular cyclic AMP (cAMP) levels and the release of incretins, including GLP-1, GIP, and glucagon-like peptide-2 (GLP-2) [16]. GLP-1 is a peptide secreted by human small intestinal L cells. It has regulatory effects on the gastrointestinal tract, blood sugar regulation, and improvement of insulin resistance, such as reducing dietary intake, increasing satiety, increasing gastrointestinal motility and prolonging the time of gastric emptying [17]. Habib et al. demonstrated that GLP-1 and peptide YY (PYY) are colocalized in L cells, suggesting that PYY is involved in reducing dietary intake [18]. Studies have shown that the fatty acid amide-induced activation of GPR119 on intestinal L cells may promote more focused and specific GLP-1/PYY activity, including inhibiting gastric emptying, regulating satiety, and inhibiting intestinal peristalsis [19]. GLP-2, a sister protein of GLP-1, is synthesized in the brain stem and released by intestinal $\mathrm{L}$ cells. It has the functions of promoting nutrient absorption, protecting the intestinal barrier, reducing intestinal permeability, and exerting anti-inflammatory effects [20-23]. GLP-2 can also reduce dietary intake, although the effect is less pronounced than that of GLP-1. Importantly, Hsieh J et al. found that GLP-2 can increase fat absorption through the stimulated CD36 pathway and can promote the release of chylomicrons, lipoprotein particles that transport exogenous hypertriglyceridemia (TG), and ultimately promote lipolysis and inhibit an increase in body weight, which is undoubtedly beneficial for patients with MAFLD [24].

GLP-1 is expressed in the body for a short time because dipeptidyl peptidase 4 (DPPIV) quickly decomposes it. Therefore, increasing the level of glucagon-like peptide or inhibiting its decomposition is of potential clinical significance for treating MAFLD. A recent study by Shuyong Zhang and others found that Gordonoside F, a steroid glycoside isolated from the African cactiform Hoodia gordonii, directly targets GPR119 to induce weight loss [25]. Even with slight weight loss, insulin resistance, abnormal blood glucose and blood pressure respond and improve quickly [21, 26]. Because GPR119 has significant advantages in blood glucose regulation, it has been a drug target to treat type 2 diabetes mellitus with many excellent results [27, 28]. Here, we update and discuss the potential therapeutic effect of the GPR119/incretin axis in MAFLD to provide a basis for the transformation of innovative clinical results of MAFLD. 


\section{Gene and tissue distribution of GPR119}

GRP119 has been described in various studies and has many aliases, such as SNORF25, GPCR2, 19AJ, OSGPR116, and glucose-dependent insulinotropic receptor [29-34]. Robert Fredriksson et al. first determined that GPR119 is an orphan receptor in the rhodopsin family [35]. Akatoshi Soga et al. confirmed, for the first time, in 2005 that GPR119 is activated by lysophosphatidylcholine (LPC), indicating that GPR119 is a de-orphanized GPCR [36]. GPR119 pertains to the biogenic amine and MECA (melanocortin, endothelial differentiation gene, cannabinoid, and adenosine) cluster of receptors [35, 37]. The human GPR119 gene is located on chromosome X at Xp26.1; it contains only one coding exon and encodes a protein of 335 amino acid bases. Also, the GPR119 gene is predicted to be widely present in other mammals, including rats, mice, rabbits, horses, and cattle. Among them, human GPR119 shares 82\%, 37\% and 73.7\% amino acid identity with mouse, fugu and rat GPR119, respectively [35].

In terms of tissue distribution, Zhi-l Ian GC and others found that compared with the entire pancreas, the expression of GRR119 is mainly distributed in the $\beta$ cell fraction of the islet population, and it is also highly expressed in the gastrointestinal tract GLP1-producing cells and GIP-producing cells, such as intestinal endocrine cells [15, 38, 39]. The main controversy is the distribution of other organs, especially in the brain and liver. Some researchers have found that GPR119 also exists in mouse liver, rat insular cortex gustatory insula, human brain, liver, skeletal muscle, and myocardium [33, 38, 40-42]. However, Odori S and others found that GPR119 mRNA was not detected in esophagus, liver or cerebrum in human tissues [43]; the different results may be due to low expression levels or differences in detection conditions. More researchers should adopt more sensitive and unified detection schemes to clarify its distribution (see Fig. 1).

\section{GPR119 ligands}

GPR119 is mainly a stimulatory G protein $\alpha$-subunit (Gas)-coupled G protein-coupled receptor [44], but it seems to be related to Gai and Gaq and can interact with $\beta$-arrestin [45]. Identifying its ligands and clarifying related physiological responses are essential to treat diseases [46]. We referenced and updated the list of ligands appropriately [15, 41]. The ligands are mainly categorized into endogenous ligands (see Table 1) and synthetic agonists (see Table 2). Many studies of GPR119 agonists have focused on their aspects of promoting insulin secretion and improving glucose tolerance. However, MAFLD is correlated with the pathological factors of T2DM, and hence GPR119 agonists have potential as therapeutic agents for alleviating MAFLD.

\section{Endogenous ligands of GPR119}

Oleoylethanolamide (OEA), LPC, retinoic acid, palmitoylethanolamide (PEA), arachidonoylethanolamide (AEA), etc., are considered to be endogenous ligands that activate GPR119 on intestinal endocrine cells (ECCs) to activate adenylate cyclase (AC), thereby increasing the downstream cAMP and increasing the release of incretins, causing a series of physiological effects [47-51]. The rank order of the effectiveness of various ligands to activate GPR119 is first OEA, then LPC, PEA, stearoylethanolamide (SEA), and finally AEA [49]. Ryouta Kogure et al. found that the $\omega-3$ unsaturated fatty 


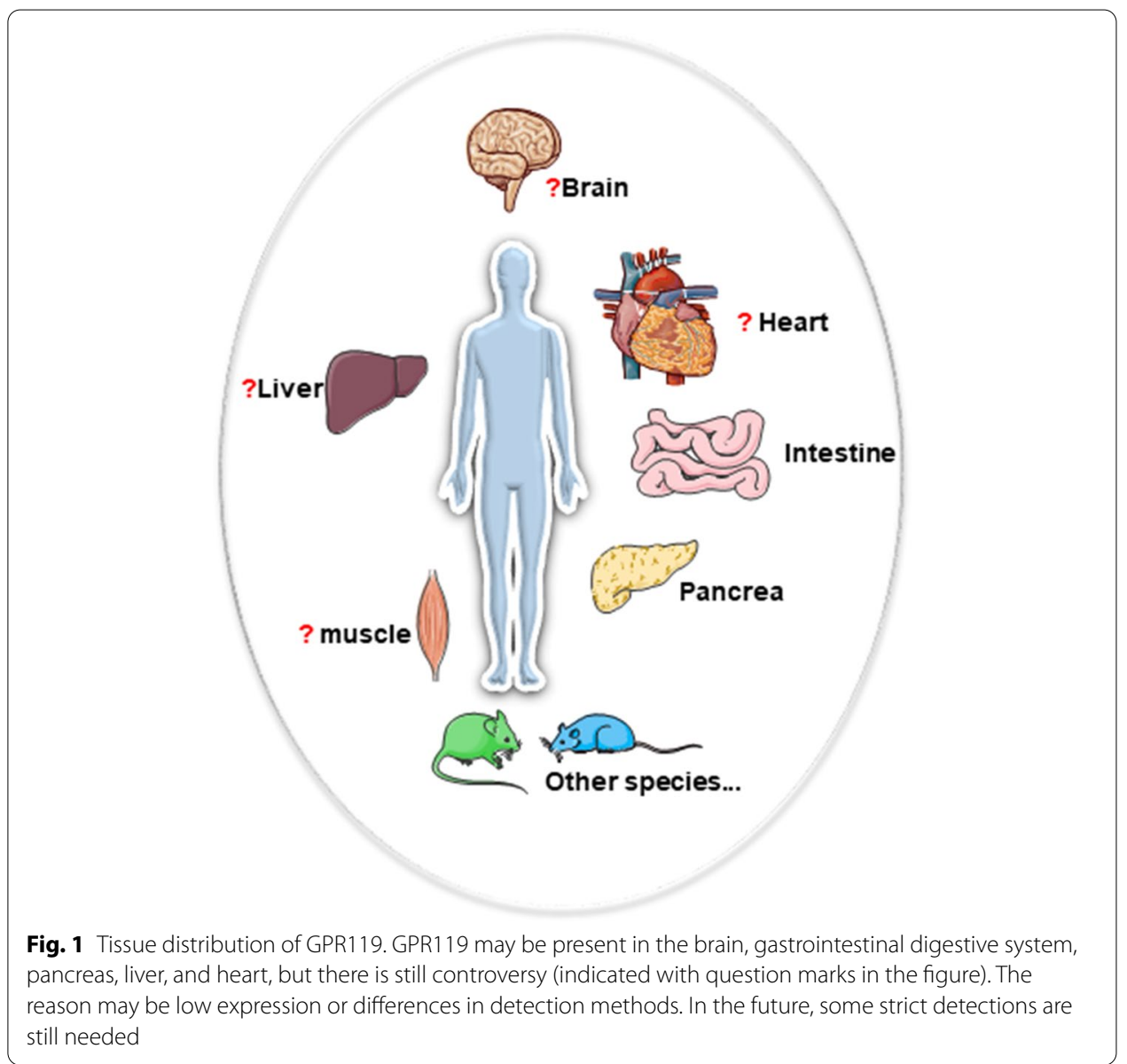

acid metabolite 5-hydroxy-eicosapentaenoic acid (5-HEPE) also activates GPR119 with an efficacy approximately equal to that of OEA [52]. $N$-oleoyldopamine (OLDA), a lipid amide, can be extracted from the bovine striatum and has been a potent endogenous ligand for GPR119 along with other hydroxybenzyl lipid amides. The potency of OLDA is equivalent to the potency of OEA [53, 54]. In addition, some lysophospholipids and other lipid breakdown products, such as LPC, oleic acid, and 1-Oleoyl glycerol (1-OG), can activate GPR119, but because of their low potency, their activity has not been determined [55].

LPC

For all the studied lysophospholipids, LPC produced by phospholipase A2 (PLA2) seems to be the most effective in activating GPR119 [55]. LPC activates GPR119 to cause glucose-dependent insulin release (GSIS). It has been a promising candidate for anti-T2DM [56]. The earliest discovery showing that LPC can promote insulin release was made by Metz et al. [57], who discovered various LPCs in 1986, including LPC 16:0, LPC 18:0, and LPC 18:1, all of which are present in human plasma [56]. Moreover, LPC, as a marker for a variety of liver diseases, is elevated in MAFLD, but saturated LPC is reduced in patients with advanced cirrhosis, and it is associated with mortality risk [58]. 
Table 1 GPR1 19 endogenous ligands

\begin{tabular}{|c|c|c|}
\hline Name & $E C_{50}(\mu \mathrm{M})$ & Refs. \\
\hline 2-Oleoyl glycerol (2-OG) & $2.5-17$ & {$[44][121][61][62]$} \\
\hline Oleoylethanolamide (OEA) & $0.2-5$ & {$[15,63]$} \\
\hline N-Oleoyl-dopamine (OLDA) & 3.2 & [53] \\
\hline Lysophosphatidylethanolamine & 5.7 & [36] \\
\hline Lysophosphatidylinositol & 5.7 & [36] \\
\hline Lysophosphatidylserine & $>30$ & [36] \\
\hline Lysophosphatidic acid & $>30$ & [36] \\
\hline Sphingosylphosphorylcholine & $>30$ & [36] \\
\hline Oleic acid & $>1000$ & [36] \\
\hline Palmitoyl-lysophosphatidylcholine (16:0-lysoPC) & $1.6-2.1$ & [36] \\
\hline Stearoyl-Iysophosphatidylcholine (18:0-lysoPC) & 3.3 & {$[36]$} \\
\hline Oleoyl-lysophosphatidylcholine (18:1-lysoPC) & $1.5-9$ & [36] \\
\hline 5-Hydroxy-eicosapentaenoic acid (5-HEPE) & $0.03-3$ & [52] \\
\hline Palmitoylethanolamide (PEA) & 0.84 & [61] \\
\hline Linoleoylethanolamide (LEA) & $0.56-5$ & [61] \\
\hline 2-Linoleoyl glycerol & 12 & [61] \\
\hline 2-Palmitoyl glycerol & 11 & [61] \\
\hline 2-Arachidonoyl glycerol & NA & {$[61]$} \\
\hline 1-Oleoyl glycerol(1-OG) & 2.8 & [61] \\
\hline 1-Linoleoyl glycerol & 36 & {$[61]$} \\
\hline Anandamide & $N A$ & {$[61]$} \\
\hline Oleamide & 4.5 & [53] \\
\hline N-Arachidonoyldopamine & NA & [53] \\
\hline N-Oleoyl-tyrosine & 0.7 & [53] \\
\hline Arachidonoyl ethanolamide (AEA) & $N A$ & [51] \\
\hline
\end{tabular}

NA not applicable

In addition, LPC can protect against hepatitis by binding to type II natural killer T cells, produce anti-inflammatory effects in inflammatory diseases, increase anti-inflammatory factor levels and reduce the production of inflammatory mediators, including interleukin-6 (IL-6) and nitric oxide (NO) [59]. In contrast, Gurunathan Murugesan et al. found that the chemotactic effect of LPC on monocyte chemotactic protein-1 (MCP-1), interleukin-8 (IL-8) and RANTES may have a pro-inflammatory effect [60]. Therefore, the role of LPC in inflammation needs further confirmation.

\section{2-Oleoyl glycerol (2-OG)}

Being among the most effective natural agonists of GPR119, OEA and 2-monoacylglycerols (2-MAGs), triglyceride metabolites, have been extensively studied, especially 2-OG. The study of Jeppe H. Ekberg et al. proved that in triglyceride metabolism, 2-OG activates GPR119 to promote the secretion of incretins, and when combined with GRP40 agonist, has a synergistic effect [44]. Whether 2-OG specifically activates GPR119 is not clear because of the instability of 2-OG itself. H.A. Hassing et al. first used 2-oleyl glyceryl, a 2-OG analog, in wild-type and GPR119-knockout mice and found that GPR119 improves glucose tolerance and is eliminated by GPR119 antagonists [16]. Katrine B. Hansen et al. used human GPR119-transfected COS-7 cells to confirm that 2-OG and 
Table 2 GPR1 19 synthetic agonists

\begin{tabular}{|c|c|c|c|c|}
\hline Name & Chemical structure & $E C_{50}(\mu \mathrm{M})$ & $\begin{array}{l}\text { Pharmacological } \\
\text { effects in vivo and } \\
\text { in vitro }\end{array}$ & Refs. \\
\hline AR231453 & & $0.0047-0.009$ & $\begin{array}{l}\text { AR231453 increases } \\
\text { the levels of cAMP, } \\
\text { GLP-1, and insulin }\end{array}$ & {$[68,71,72]$} \\
\hline PSN821 & Structure not disclosed & NA & $\begin{array}{l}\text { PSN821 can reduce } \\
\text { weight and increase } \\
\text { GLP-1 levels }\end{array}$ & {$[79,122]$} \\
\hline MBX-2982 & & 0.0039 & $\begin{array}{l}\text { MBX-2982 increases } \\
\text { GLP-1 secretion, } \\
\text { improves blood glu- } \\
\text { cose control, inhibits } \\
\text { fat production and } \\
\text { reduces cholesterol }\end{array}$ & {$[123,124]$} \\
\hline GSK1292263 & & NA & $\begin{array}{l}\text { GSK1292263 reduces } \\
\text { HbA1c levels and } \\
\text { glucose excursion }\end{array}$ & {$[123,125]$} \\
\hline LEZ763 & Structure not disclosed & NA & NA & [79] \\
\hline JNJ-38431055 & & 0.046 & $\begin{array}{l}\text { JNJ-38431055 reduces } \\
\text { glucose excursion }\end{array}$ & {$[55,76]$} \\
\hline DS-8500a & & 0.0515 & $\begin{array}{l}\text { DS-8500a improves } \\
\text { abnormal glu- } \\
\text { cose intolerance, } \\
\text { increases GLP-1, } \\
\text { insulin secretion } \\
\text { and high-density } \\
\text { lipoprotein choles- } \\
\text { terol concentrations, } \\
\text { reduces total cho- } \\
\text { lesterol, low-density } \\
\text { lipoprotein choles- } \\
\text { terol and triglyceride } \\
\text { concentrations }\end{array}$ & [126-132] \\
\hline ZYG-19 & Structure not disclosed & $N A$ & $N A$ & [79] \\
\hline AR246881 & & 0.0097 & NA & [76] \\
\hline BMS-903452 & & 0.014 & $\begin{array}{l}\text { BMS- } 903452 \text { reduces } \\
\text { glucose excursion, } \\
\text { increases GLP-1 and } \\
\text { insulin secretion }\end{array}$ & [79] \\
\hline AR44006 & Structure not disclosed & 0.1704 & $\begin{array}{l}\text { AR44006 increases } \\
\text { insulin secretion }\end{array}$ & {$[63]$} \\
\hline AR435707 & Structure not disclosed & 0.0277 & $\begin{array}{l}\text { AR435707 increases } \\
\text { insulin secretion }\end{array}$ & {$[63]$} \\
\hline
\end{tabular}


Table 2 (continued)

\begin{tabular}{|c|c|c|c|c|}
\hline Name & Chemical structure & $\mathrm{EC}_{50}(\mu \mathrm{M})$ & $\begin{array}{l}\text { Pharmacological } \\
\text { effects in vivo and } \\
\text { in vitro }\end{array}$ & Refs. \\
\hline $\begin{array}{l}\text { GSK- } \\
1104252 \mathrm{~A}\end{array}$ & & 0.05 & NA & [79] \\
\hline APD668 & & 0.0027 & $\begin{array}{l}\text { APD668 reduces cho- } \\
\text { lesterol, TG levels, } \\
\text { body weight ALT } \\
\text { and AST }\end{array}$ & [55] \\
\hline ARN-II & & NA & $\begin{array}{l}\text { ARN-II enhances GLP-1 } \\
\text { secretion, increases } \\
\text { CAMP level }\end{array}$ & [133] \\
\hline$A Z 1$ & & NA & $\begin{array}{l}\text { AZ1 enhances GLP-1 } \\
\text { secretion, increases } \\
\text { cAMP level }\end{array}$ & [133] \\
\hline AZ2 & & $N A$ & $\begin{array}{l}\text { AZ2 enhances GLP-1 } \\
\text { secretion, increases } \\
\text { cAMP level }\end{array}$ & [133] \\
\hline AZ3 & & NA & $\begin{array}{l}\text { AZ3 enhances GLP-1 } \\
\text { secretion, increases } \\
\text { cAMP level }\end{array}$ & [133] \\
\hline AS1269574 & & 2.5 & $\begin{array}{l}\text { AS1269574 protects } \\
\text { B cell function and } \\
\text { alleviates disorders } \\
\text { of glucose and lipid } \\
\text { metabolism }\end{array}$ & [134] \\
\hline AS1535907 & & $1.5-4.8$ & $\begin{array}{l}\text { AS1535907 protects } \\
\beta \text { cell function and } \\
\text { promotes insulin } \\
\text { secretion }\end{array}$ & [135-137] \\
\hline AS1907417 & & 1.1 & $\begin{array}{l}\text { AS1907417 enhances } \\
\text { intracellular cAMP, } \\
\text { GSIS, and human } \\
\text { insulin promoter } \\
\text { activity and regu- } \\
\text { lates adipogenesis }\end{array}$ & [91] \\
\hline AS1669058 & & 0.11 & $\begin{array}{l}\text { AS1669058 improves } \\
\text { glucose tolerance } \\
\text { and promotes insu- } \\
\text { lin secretion }\end{array}$ & [79] \\
\hline
\end{tabular}


Table 2 (continued)

\begin{tabular}{|c|c|c|c|c|}
\hline Name & Chemical structure & $\mathrm{EC}_{50}(\mu \mathrm{M})$ & $\begin{array}{l}\text { Pharmacological } \\
\text { effects in vivo and } \\
\text { in vitro }\end{array}$ & Refs. \\
\hline PSN119-2 & & 0.4 & NA & {$[76,79]$} \\
\hline PSN632408 & & 1.9 & $\begin{array}{l}\text { PSN632408 could } \\
\text { increase the CAMP } \\
\text { level and insulin } \\
\text { secretion }\end{array}$ & [138] \\
\hline PSN375963 & & 8.4 & $\begin{array}{l}\text { PSN375963 increases } \\
\text { insulin and GLP-1 } \\
\text { secretion }\end{array}$ & {$[40]$} \\
\hline PSN119-1 & & 0.5 & $\begin{array}{l}\text { PSN119-1 increases } \\
\text { insulin and GLP-1 } \\
\text { secretion }\end{array}$ & [139] \\
\hline PSN119-1 M & & 0.2 & $\begin{array}{l}\text { PSN1 19-1 M increases } \\
\text { insulin and GLP-1 } \\
\text { secretion }\end{array}$ & [139] \\
\hline Compound 3 & & 1.7 & $\begin{array}{l}\text { Compound } 3 \\
\text { increases insulin and } \\
\text { GLP-1 secretion }\end{array}$ & [139] \\
\hline Compound 1 & & 0.5 & $\begin{array}{l}\text { Compound } 1 \\
\text { increases insulin and } \\
\text { GLP-1 secretion }\end{array}$ & [139] \\
\hline HD0471953 & Structure not disclosed & NA & $\begin{array}{l}\text { HD0471953 can } \\
\text { improve glucose tol- } \\
\text { erance and increase } \\
\text { cAMP level }\end{array}$ & [83] \\
\hline HD044703 & structure not disclosed & 0.11 & $\begin{array}{l}\text { HD044703 can } \\
\text { improve glucose tol- } \\
\text { erance and enhance } \\
\text { CAMP, GLP-1 and } \\
\text { insulin secretion }\end{array}$ & [140] \\
\hline HD0471042 & Structure not disclosed & $0.65-0.85$ & $\begin{array}{l}\text { HD0471042 can } \\
\text { improve glucose tol- } \\
\text { erance and enhance } \\
\text { CAMP, GLP-1 and } \\
\text { insulin secretion }\end{array}$ & [141] \\
\hline
\end{tabular}


Table 2 (continued)

Name Chemical structure

NA not applicable

other monoacylglycerols activated GPR119 to increase the secretion of GLP-1 and other hormones and suggested that GPR119 acts as a fat sensor [61]. Interestingly, Karen Kleberg et al. found that 2-OG formed by lipoprotein esterase (LDL) acts as a lipid signal transducer in the vascular system [62].

\section{Oleoylethanolamide (OEA)}

OEA, as an endogenous fatty acid derivative, is a natural agonist of GPR119 [15, 63]. OEA is a peroxisome proliferator activated receptor $\alpha$ (PPAR- $\alpha)$ agonist that reduces food intake and promotes lipid oxidation [64]. In addition, OEA may reduce fat gain in high-fat diet mice by activating the GPR119 pathway [65]. Studies have shown that bile acids regulate OEA production and activate GPR119 to regulate gastric emptying and increase satiety in experimental mouse models [66]. Hilary A. Overton et al. found that GPR119 at least partially mediated the effect of OEA on food intake, and they orally administered to rats PSN632408, a new agonist of GPR19, which inhibited food intake and white fat accumulation [40]. Similarly, Flock, Grace et al. used AR6231453, a GPR119 agonist, and found that it inhibited gastric emptying through a GPR119dependent pathway and prolonged gastric emptying time [67]. However, it is still unclear whether the gastric inhibitory effect of OEA-activated GRP119 is specific. Hong Lan et al. used GPR119-knockout mice to find that GPR119 is unnecessary for the gastric inhibitory effect of OEA [68]. Moran et al. found that the gastric inhibitory effect produced by OEA may involve pancreatic polypeptide (PPY) [50]. OEA can trigger effects similar to those observed after bariatric surgery, including reduced food intake, reduced fat mass, increased GLP-1 release, and reduced lipid levels, which are undoubtedly beneficial to patients with MAFLD [69]. 


\section{Synthetic GPR119 ligands}

Because of the great attraction of targeting GPR119 to T2DM, many synthetic GPR119 agonists have appeared. Here are some of the ligands and pharmacological effects of synthetic GPR119.

\section{AR231453}

AR231453 is the first GPR119 agonist developed by Arena Pharmaceuticals $(\mathrm{EC} 50=0.0047-0.009 \mathrm{uM})[70,71]$. Chu et al. found that AR231453 strongly stimulated glucose-dependent insulin release and cAMP accumulation by testing in cells transfected with human GPR119 and rat islets, but there was almost no response in GPR119deficient mice or those lacking GPR119 cells [68]. Also, Marty et al. found that the use of AR231453 significantly increased the release of GLP-1 from rat intestinal L cells [72]. AR231453 has been used in several pre-clinical studies on diabetes, showing that it can regulate glucose homeostasis and increase the secretion of incretins [73, 74]. It is worth noting that GPR119 expression within murine B cells may not be important for the response to hyperglycemia or the direct insulin secretion response to GRP119 agonists in isolated mouse pancreatic islets and GPR119 $\beta$-cell-deficient mice [75].

\section{APD597}

APD597, also known as JNJ-38431055, is a synthetic GPR119 agonist. Some clinical trials are currently ongoing or completed to evaluate its pharmacokinetics, safety, tolerability, and role in obesity and T2DM. Semple et al. fount that JNJ-38431055 (3-30 mg/ $\mathrm{kg}$ PO) significantly improved the glucose excursion of diabetic experimental rats [76]. Studies have demonstrated that oral administration of APD597 is safe and well tolerated, and it can increase the secretion of incretin and insulin and decrease incremental plasma glucose excursion during oral glucose tolerance test in T2DM patients, but the final hypoglycemic effect is not ideal [77]. In a double-blind, randomized and placebocontrolled study, oral JNJ-38431055 (2.5-800 mg) in healthy male volunteers is also safe and well tolerated, and it can increase the concentrations of GLP-1, GIP, and PYY. Compared with the placebo group, APD597 did not significantly increase insulin secretion or glucose excursion, but it had a higher insulin secretion rate in a graded glucose infusion study [78].

\section{AS1669058}

AS1669058 $\left(\mathrm{EC}_{50}=0.11 \mu \mathrm{M}\right)$ is a new generation of GPR119 small molecule agonist reported by Astellas company and further improved from AS1269574 $\left(\mathrm{EC}_{50}=2.5 \mu \mathrm{M}\right)$ [79]. Oshima et al. found that AS1669058 dose-dependently stimulates insulin secretion in HIT-H15 cells and isolated rat pancreatic islets. Administration of $1 \mathrm{mg} / \mathrm{kg}$ of AS1669058 significantly improved the glucose tolerance of ICR mice, and administration of $3 \mathrm{mg} / \mathrm{kg}$ of AS1669058 twice a day for a week reduced the glucose level of $d b / d b$ mice [80].

\section{Others}

There are still many synthetic GPR119 agonists, including PSN632408, HD0471953, MBX2982, GSK1292263, and BMS903452, and some are undergoing clinical trials (see 
Tables 2 and 3), most of which concern their role in T2DM. It was found that PSN632408 could increase the cAMP level and insulin secretion of HEK293 cells transfected with GPR119 [81]. In 2019, Fang et al. synthesized and evaluated a series of novel fused pyrimidine derivatives as GPR119 agonists; some of these analogs $(16,19,26,28,42)$ have high GPR119 agonistic activity [82]. Single dose administration of HD0471953 can improve the oral glucose tolerance test (OGTT) in normal C57BL/6 J mice, and increase insulin secretion and GLP-1 level. Also, HD0471953 stimulates a dose-dependent increase in cAMP levels in the HIT-T15 $\beta$ cell line, and it reduces the body weight, high-density lipoprotein (HDL), LDL cholesterol, TG and epididymal fat in experimental T2DM mice [83]. Compared with normal mice, BMS903452 at the dose of 0.1-0.3 mg/ $\mathrm{kg}$ reduced the glucose excursion by $30-40 \%$ in an OGTT, BMS903452 and a DPP-IV inhibitor synergistically regulated GLP-1 levels in a Sprague-Dawley rat model, and BMS903452 (0.03 mg/kg/day) reduced fasting blood glucose levels and increased insulin secretion in $d b / d b$ mice [79]. BMS903452 at 0.1-120 mg was safe and tolerable to healthy subjects in a clinical trial, but no significant increase in plasma total GLP-1 level was observed in the first $24 \mathrm{~h}$ of treatment [84].

\section{The relationship between the GPR119/incretin axis and MAFLD}

The secretory response of incretins is due to the activation of enteroendocrine cells after food intake by the intestinal system. The principle incretins are GIP and GLP-1, produced by $\mathrm{K}$ cells in the proximal gut and $\mathrm{L}$ cells in the distal gut, respectively [85]. GPR119 activated by various factors can promote the secretion of incretins, which may attenuate MAFLD, including its effect on sugar metabolism, lipid metabolism, inflammation, and the intestinal micro-ecosystem. This process may involve the cAMP/ protein kinase A (PKA)/cAMP response element-binding protein (CREB) and extracellular signal-regulated protein kinase 1 and 2 (ERK1/2) pathways. When GPR119 is activated by a variety of endogenous and exogenous factors, heterotrimeric G-protein activates adenylate cyclase $(\mathrm{AC})$ and then activates $\mathrm{PKA} /$ mitogen-activated protein kinase kinase1/2(MEK1/2)/ERK1/2 protein sequentially to play a physiological role. The primary source of AC is adenosine triphosphate (ATP) mediated by the Class-III AC/ ADCY (adenylate cyclase) family. PKA enhances intracellular calcium influx through the phosphorylation of voltage-dependent calcium channel (VDCC), thus increasing insulin secretion [86] (see Fig. 2).

\section{The GPR119/incretin axis enhances glucose metabolism}

Insulin resistance and hyperglycemia accompany glucose metabolism disorders in MAFLD patients, and hyperglycemia increases the production of intracellular reactive oxygen species (ROS), which destroy mitochondrial function and lead to hepatocyte apoptosis, which aggravates MAFLD [87-89]. The GPR119/incretin axis may have unique advantages for attenuating hyperglycemia. Huan et al. discovered that HBK001, a new candidate GPR119 agonist and DPP4 inhibitor, promotes the release of GLP-1, improves glucose tolerance and protects islet $\beta$ cell function [90]. Furthermore, Kim et al. found that HD0471953, a GPR119 agonist, attenuates disorders of insulin sensitivity and blood sugar control [83]. Yoshida et al. found that AS1269574 protects $\beta$ cells function and alleviates disorders of glucose and lipid metabolism by reducing triglyceride and 


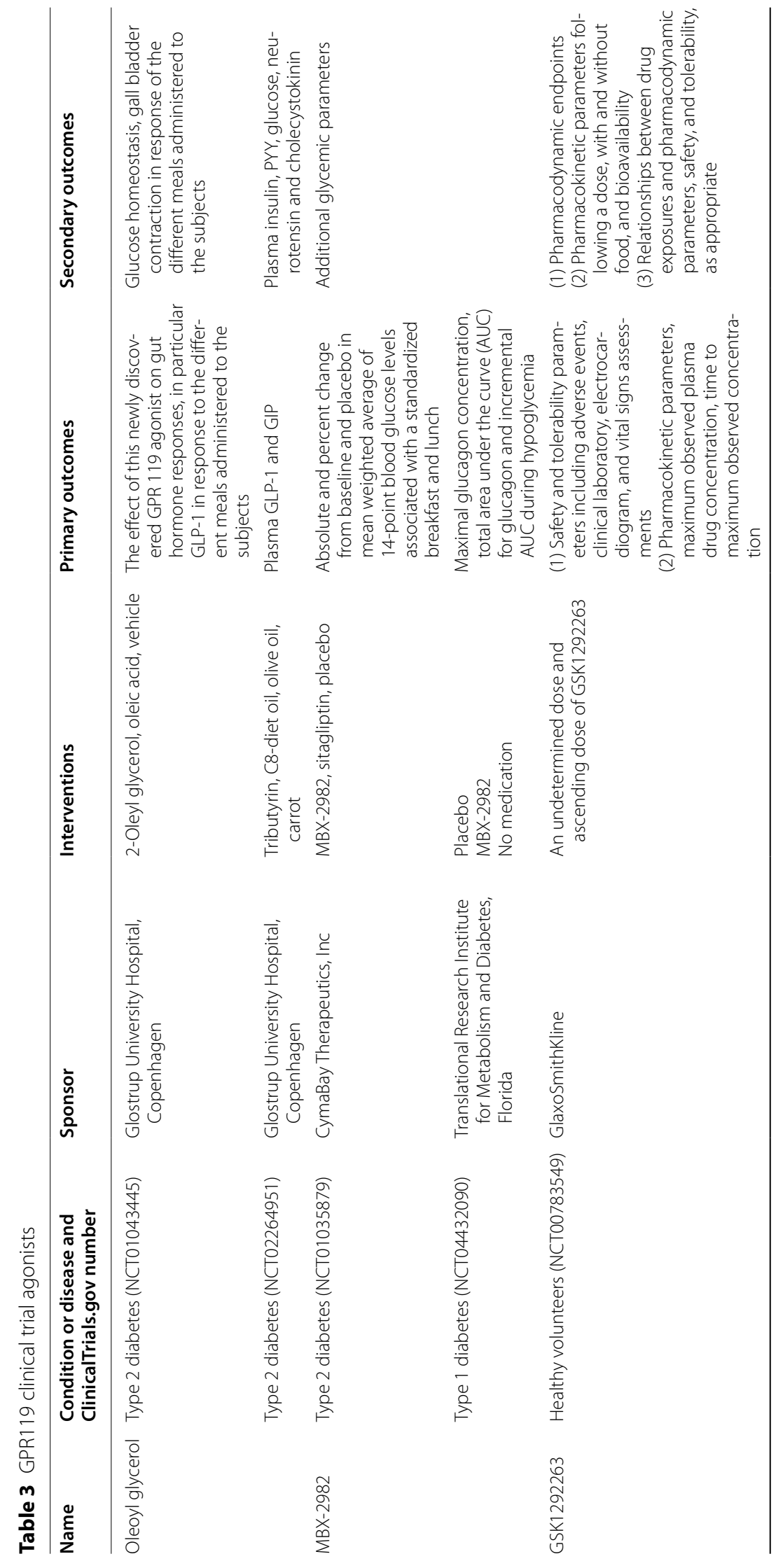




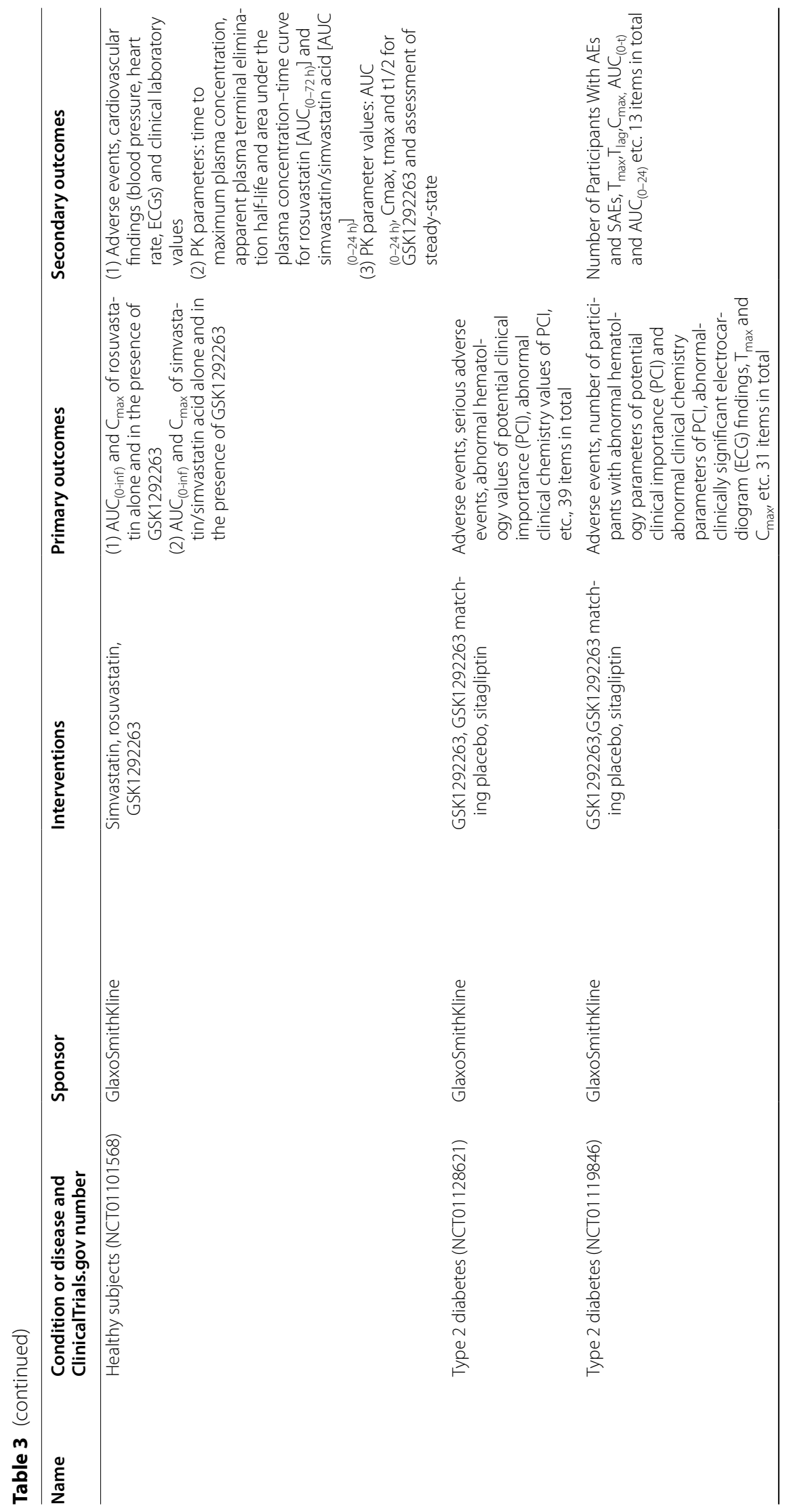




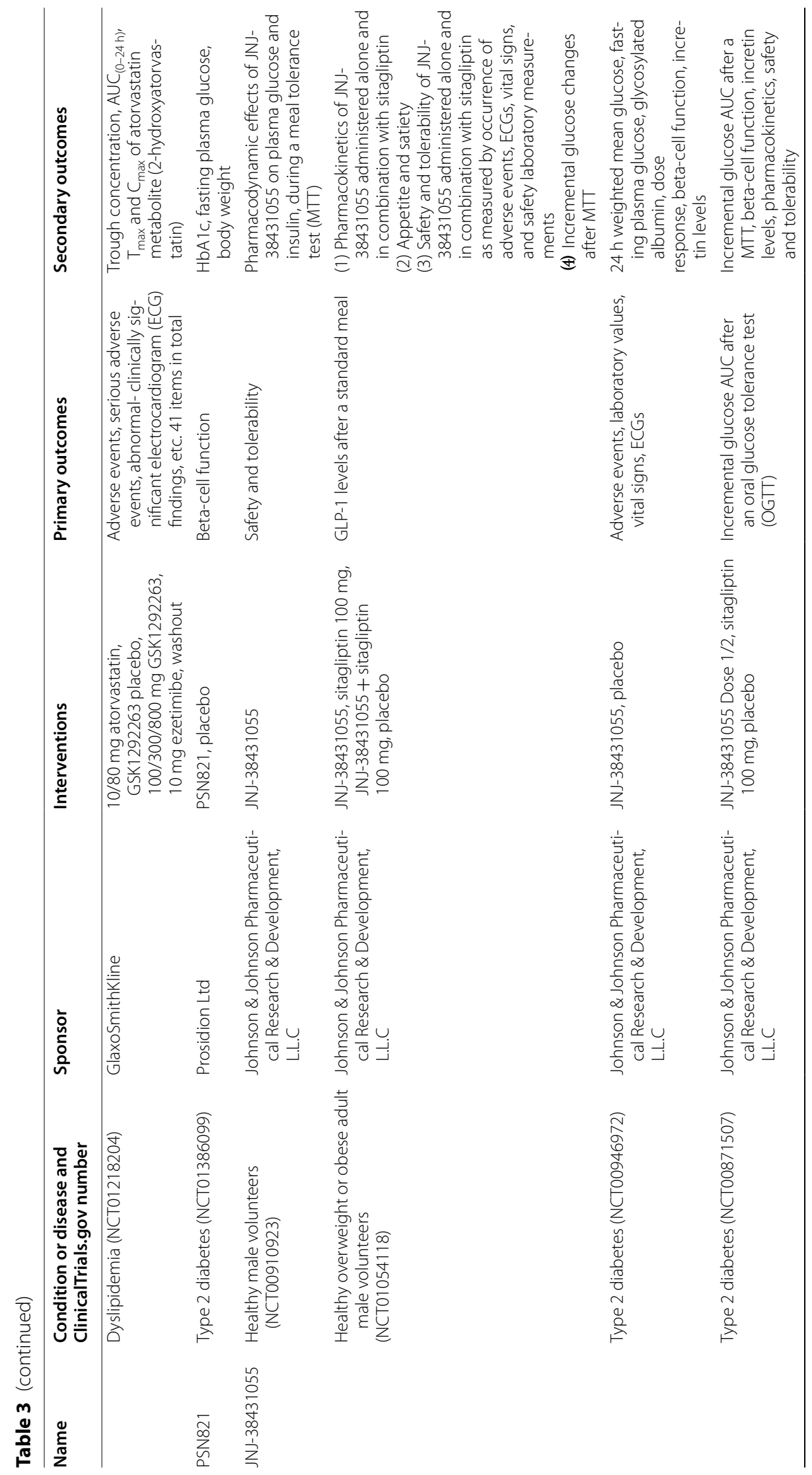




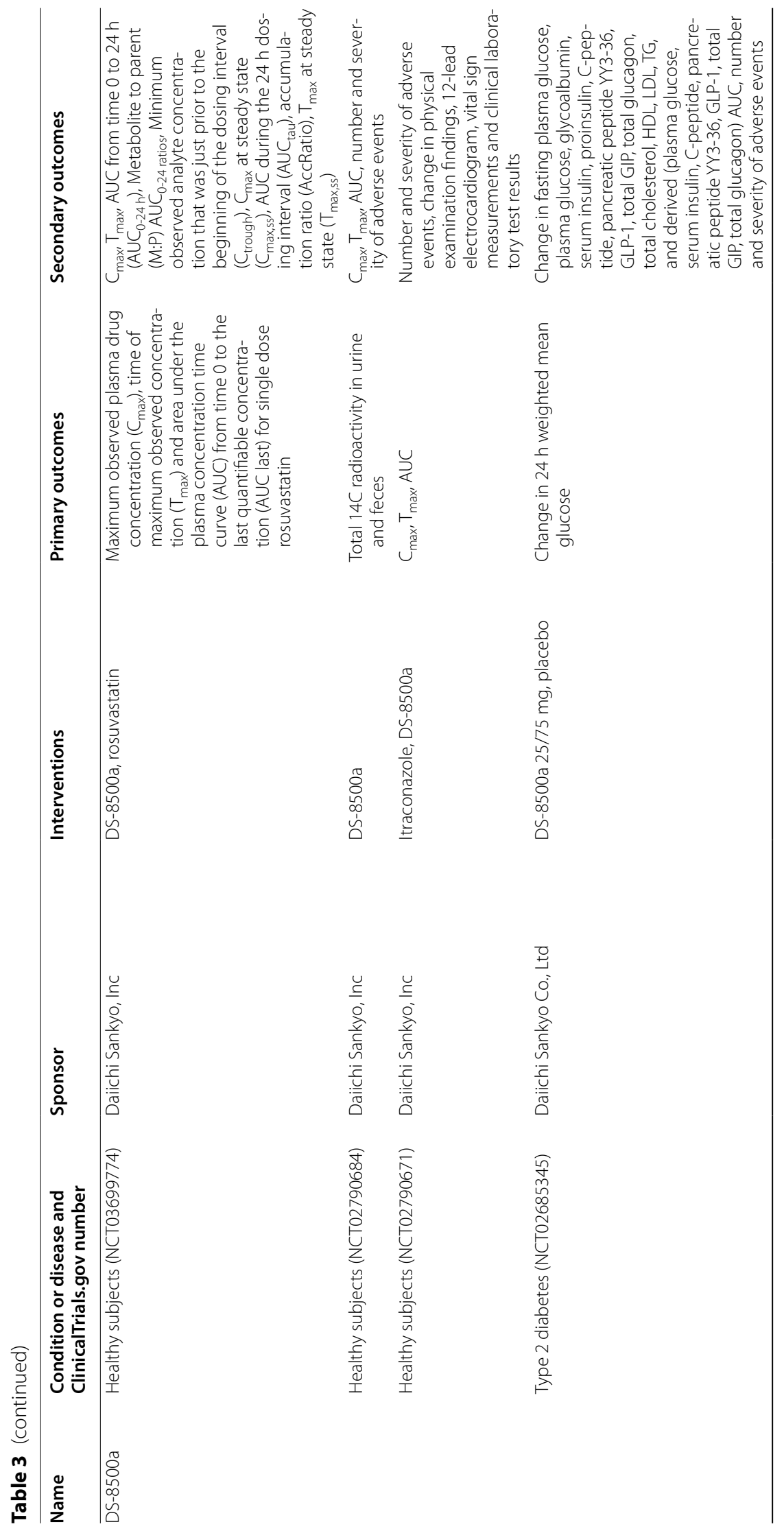




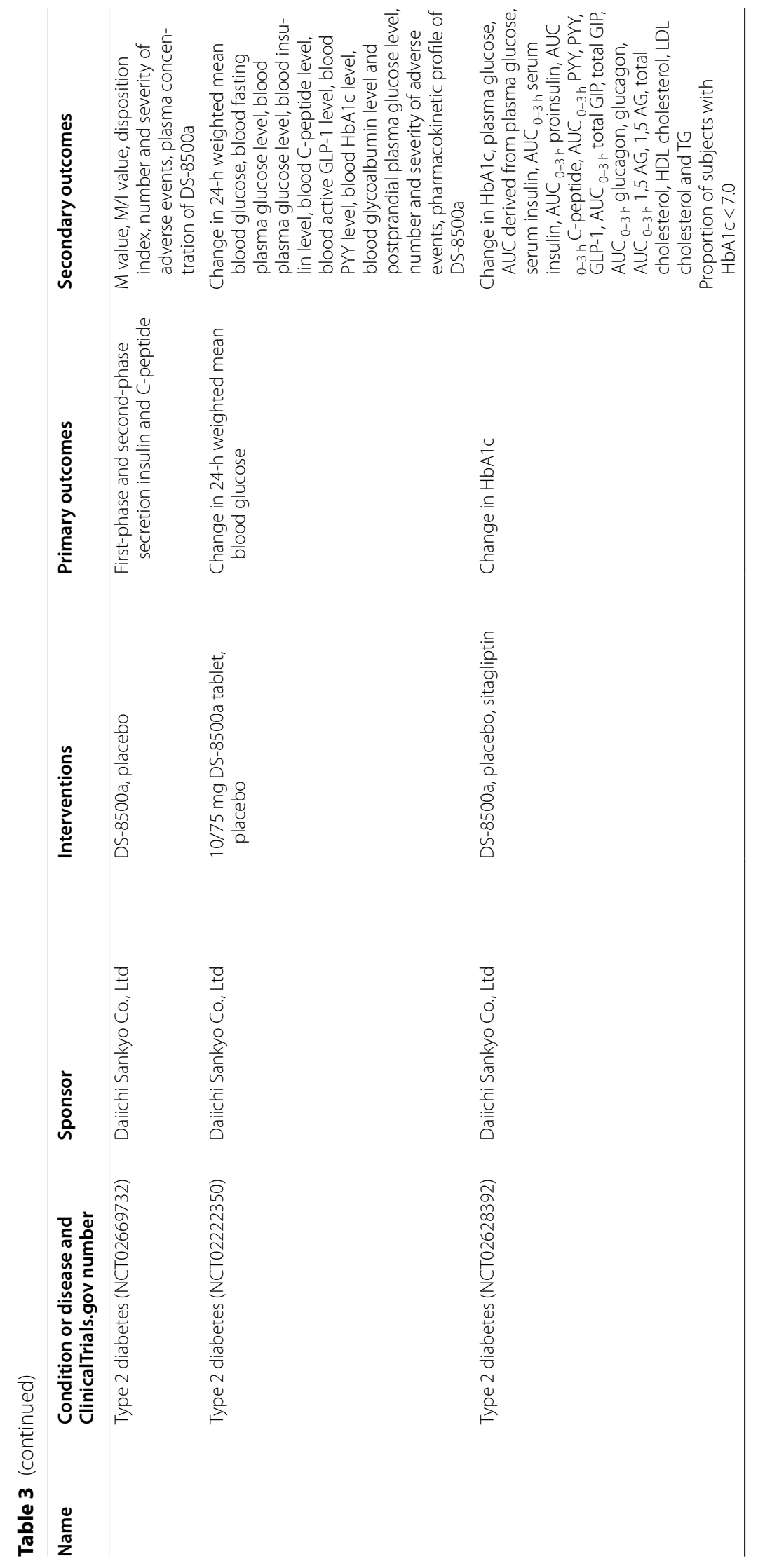




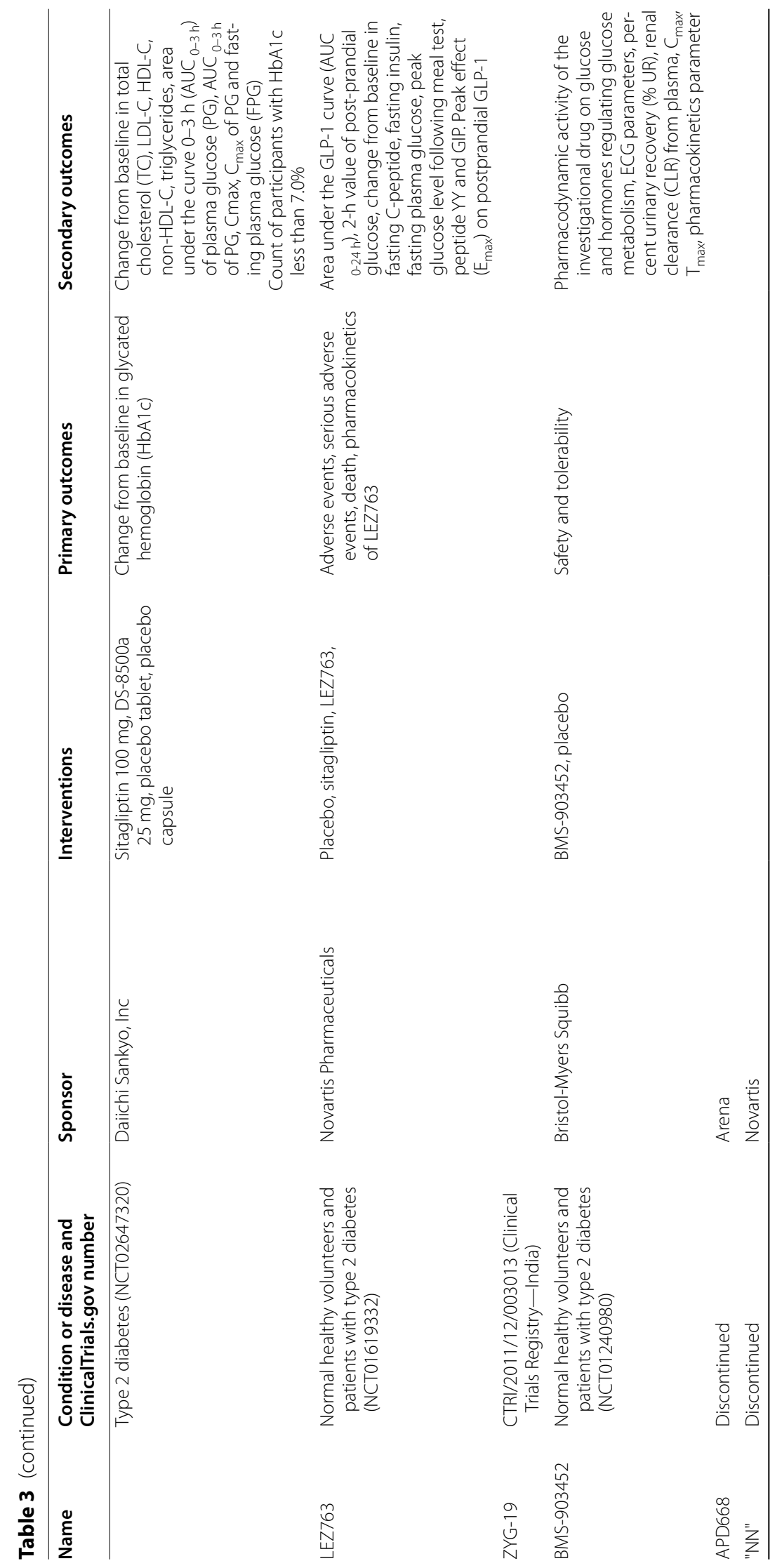




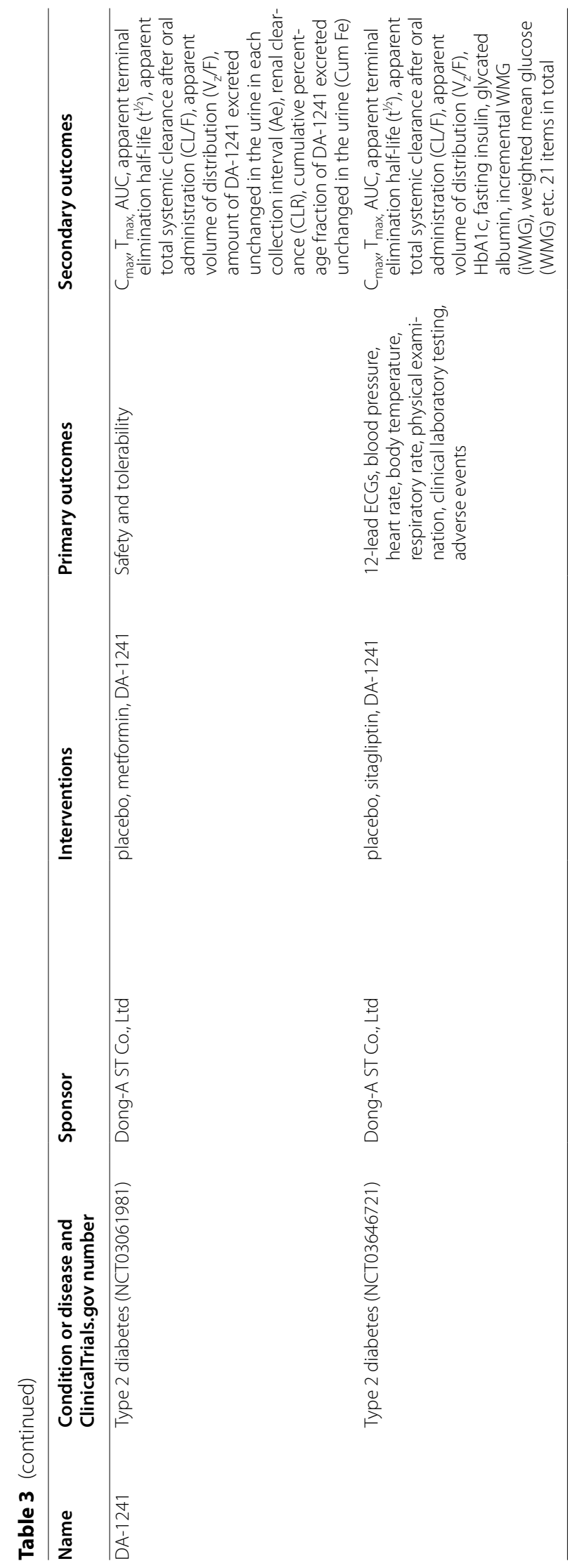


non-esterified free fatty acid (NEFA) levels in the body [91]. Studies have shown that AS1907417 in three cell lines, HEK293 cells, NIT-1 cells, and MIN-6-B1 cells, enhances intracellular cAMP, GSIS, and human insulin promoter activity and regulates adipogenesis [91]. Therefore, further attention should be paid to its unique advantages in lipid metabolism.

\section{The GPR119/incretin axis enhances lipid metabolism}

MAFLD patients often present with reduced glycolysis and very low-density lipoprotein (VLDL) output due to insulin resistance and other factors; thus, TG levels in the liver increase, and TG accumulates in liver cells, causing liver cell degeneration, inflammation and insulin resistance in the liver to worsen, forming a vicious cycle. Studies have shown that lipid infusion increases the expression of GPR119 in volunteers [92]. The increase in cAMP caused by the GPR119/incretin axis can protect $\beta$ cells from oxidative damage and lipid-induced apoptosis [93, 94]. The agonist-induced GPR119/incretin axis can reduce stearoyl-coA desaturase -1(SCD-1) mRNA levels by attenuating insulin resistance, leading to decreased liver adipogenesis [95]. Kim et al. used DA-1241, a GPR119 agonist, to inhibit adipogenesis and reduce steatosis through the inactivation of sterol regulatory element-binding protein-1c (SREBP-1c), the key factor of adipogenesis mediated by AMPK signaling [96]. Similarly, MBX-2982/GSK1292263, after the second phase of a clinical trial on synthetic ligands, was confirmed to function through the same mechanism as in liver cells and HepG2 cells to inhibit fat production and reduce cholesterol [38]. Bahirat et al. found that the use of APD668 alone in an MAFLD mouse model induced by a high-fat diet (HFD) can lower cholesterol and TG levels, reduce body weight and improve insulin resistance. In particular, when used together with linagliptin, a DPP4 inhibitor, APD668, may reduce liver steatosis, attenuate weight gain, and reduce alanine aminotransferase (ALT) and aspartate aminotransferase (AST) levels by inhibiting lipogenic-related gene (SREBP-1c, FASN and SCD-1) levels. The authors speculate that the direct activation of GPR119 and the prolonged time of GLP-1 may cause its effect. Using a DPP4 inhibitor or GLP-1 agonist alone can reduce fat formation, activate the AMP-activated protein kinase (AMPK) pathway and enhance insulin sensitivity. The combined use of the two agents has a synergistic effect, suggesting their combination in the treatment of MAFLD [97-100]. Nitika Arora Gupta et al. used HepG2 and Huh7 cells to prove that GLP-1 can act on glucagon-like peptide-1 receptor (GLP$1 R$ ), another GPCR, thereby reducing the content of TG in the liver [101]. Therefore, the GPR119/incretin axis may have a synergistic effect with other GPCR receptors. In addition, Psichas et al. found that chylomicrons, lipoprotein particles that transport exogenous TG, hydrolyze TG into long-chain fatty acids (LCFAs) and monomers through an independent mechanism with the participation of lipoprotein esterase (LPL), which GPR119 recognizes to enhance the release of incretins [26]. The GPR119/incretin axis not only has advantages in regulating TG content but is also quite effective in lowering cholesterol. Recently, Yan-Wei Hu et al. found that oxidized LDL induces the expression of lincRNA-DYNLRB2 to upregulate GPR119 and ABCA1, an essential protein in anticholesterol transport, which increases apoA-I-mediated cholesterol efflux and inhibits related inflammatory factor expression [102]. Importantly, GPR119 agonists such as 
APD668 and GSK1292263 were also found to reduce cholesterol levels, although the mechanism is not yet clear $[79,100]$.

\section{The GPR119/incretin axis and inflammation}

In MAFLD, hepatic steatosis and intestinal microbial secretions can activate Kupffer cells (KCs) to release proinflammatory factors, such as TNF- $\alpha$, IL- 6 , and interleukin-1 $\beta$ (IL-1 $\beta$ ), which cause inflammation [103]. Magdalena Grill et al. found that an increase in the endogenous ligand OEA of GPR119 may exert an anti-inflammatory effect in inflammatory bowel disease [104]. Similarly, as mentioned above, the endogenous GPR119 ligand LPC also has anti-inflammatory effects. Notably, the effect of GPR119/incretins on inflammation seems to be achieved by indirectly enhancing GLP-1. By using the normal mouse model of stably expressed rAd-GLP-1, Y.-S. Lee et al. found that GLP-1 can reduce not only fat accumulation but also the expression of pro-inflammatory factors,

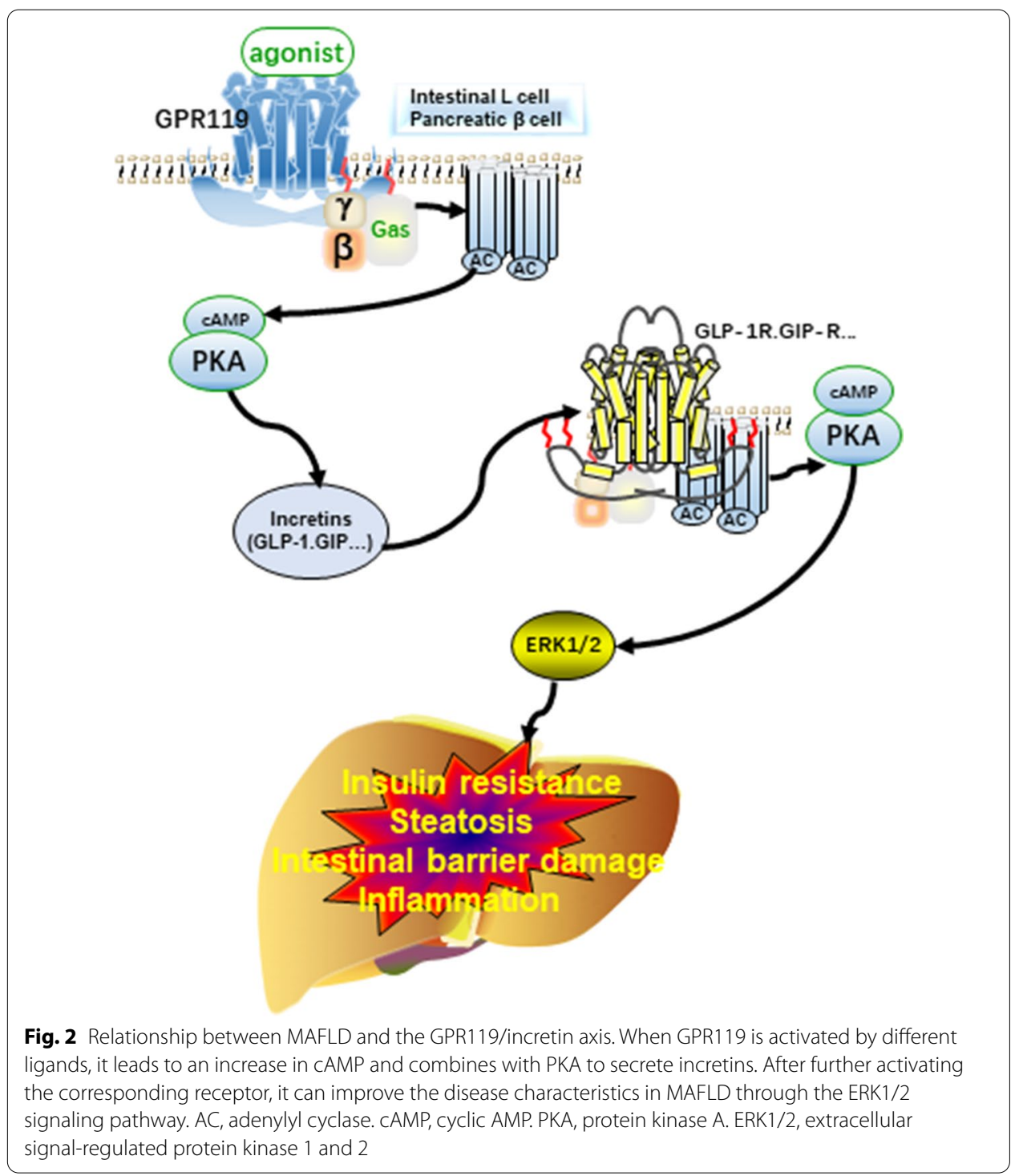


such as TNF- $\alpha$, IL-6, and macrophage infiltration and inflammatory pathways, thereby inhibiting inflammation [105]. GLP-1 can inhibit IL-1, interleukin-18 (IL-18), and nuclear factor-kappa B (NF- $\mathrm{kB}$ ) to reduce inflammation in adipose tissue [106]. In summary, its correlation with inflammation deserves further experimental exploration.

\section{The GPR119/incretin axis regulates gut microbes}

The intestine has an enormous surface area and diverse functions. As one of the important organs of the human body, the intestine is host to microbes that act as media for communication with the outside world and are indispensable for human health [107, 108]. Recently, Chepurny et al. found that AS1269574 acts as a dual agonist to activate GPR119 and TRPA1 cation channels to promote calcium influx and the release of incretin hormones, suggesting the possibility that the dual effects of the intestinal liver axis and quantum channels can be controlled [109]. Cohen et al. used bioinformatics to find that the part encoded by the $N$-acyl amide gene of human symbiotic bacteria interacts with GPR119 by mimicking human lipid signaling molecules, such as 2-OG, showing a way to treat metabolic diseases thought to regulate intestinal microbes [110]. Fitriakusumah et al. found that MAFLD is significantly associated with the overgrowth of intestinal flora [111]. The overgrowth of intestinal flora in MAFLD patients can cause changes in the permeability of the intestinal mucosa and the destruction of tight junction structures, resulting in lipopolysaccharides (LPS) and other substances entering the blood, and they interact with Toll-like receptors through NF-kB and other pathways, producing inflammatory mediators and triggering chronic inflammation and insulin resistance (IR) [112, 113]. Lund et al. found that activation of endogenous GPR119 promotes enteroendocrine cells to enhance the release of serotonin. Although it may have a pro-inflammatory effect, in most cases, the latter can protect the intestinal barrier and secrete intestinal protective mucus $[114,115]$. After activation of GPR119, the release of GLP-2 has a protective effect on the intestinal barrier and inflammation. Patrice D Cani et al. found that the use of GLP-2 antagonists abrogated the improvements to the intestinal barrier induced by intestinal microbes, suggesting a specific effect between intestinal L cells and intestinal microflora [108]. Recently, Png CW et al. discovered that a gut microbe, $A$. muciniphila, is related to several diseases with increased intestinal permeability $[116,117]$. Amandine Everard et al. used this bacterial treatment to improve endotoxemia, inflammation, and insulin resistance related to metabolic disorders. It has been proven that this bacterial treatment can increase 2-OG levels. Importantly, 2-OG can also activate GPR119 [118].

\section{Future prospects and challenges}

Metabolex and Sanofi-Aventis signed a massive investment agreement to develop the latest GPR119 pharmacological agent. Although there are currently approved injections of liraglutide and exenatide that directly target GLP-1, the discovery of GPCRs has led to opportunities for innovative development of oral active drugs [119], and there are many clinical GPR119 agonists (see Table 3). GPR119 is highly expressed in the digestive system, such as the gastrointestinal pancreas, and there is little evidence that it is expressed in the human central nervous system; thus adverse side effects in the nervous system are avoided. Another problem for GPR119 treatment is the development of related 
candidate compounds. Although there are currently excellent specific GPR119 agonists, their efficacy is another competing element affecting the future drug development market, and there are excellent comments and discussions about this aspect of drug development [79]. Although most of the current clinical trials of GPR119 have focused on treating T2DM, and some of the experimental results are not ideal, the safety and tolerability of MBX-2982 and PSN821 are worthy of recognition, and GLP-1 secretion is increased. Therefore, as long as chronic metabolic diseases such as MAFLD continue to exist and no specific drug is found, comprehensive investigation into potential effects of GPR119 and well-designed clinical trials still need to be conducted. In addition, the GPR119 sequence of rodents and humans are different, so there may be differences in the translation of results based on various rodent experimental models to clinical practice, which is also an important factor that should be considered [120].

\title{
Conclusion
}

The GPR119/incretin axis may have a protective effect on MAFLD through a series of physiological effects by attenuating insulin resistance, reducing fat production, reducing dietary intake, reducing weight gain, increasing cholesterol outflow, and interacting with intestinal microbes. However, as a Gas-coupled receptor, GPR119 has a single pathway of action that may provide only a small contribution to the attenuation of metabolic diseases, and there may be synergy between receptors of different coupling pathways. Therefore, further research is urgently needed in the future to determine the effect that may be related to the GPR119/incretin axis and convert it into an effective clinical MAFLD treatment plan.

\begin{abstract}
Abbreviations
MAFLD: Metabolic (dysfunction)-associated fatty liver disease; NAFLD: Non-alcoholic fatty liver disease; T2DM: Type 2 diabetes mellitus; GPCR: G protein-coupled receptor; GLP-1: Glucagon-like peptide-1; GIP: Glucose-dependent insulinotropic peptide; CAMP: Cyclic AMP; GLP-2: Glucagon-like peptide-2; PYY: Peptide YY; TG: Triglyceridemia; DPPIV: Dipeptidyl peptidase 4; LPC: Lysophosphatidylcholine; MECA: Melanocortin, endothelial differentiation gene, cannabinoid, and adenosine; Gas: G protein a-subunit; OEA: Oleoylethanolamide; PEA: Palmitoylethanolamide; AEA: Arachidonoyl ethanolamide; ECCs: Endocrine cells; AC: Adenylate cyclase; SEA: Stearoylethanolamide; 5-HEPE: 5-Hydroxy-eicosapentaenoic acid; OLDA: N-oleoyl dopamine; 1-OG: 1-Oleoyl glycerol; PLA2: Phospholipase A2; GSIS: Glucose-dependent insulin release; IL-6: Interleukin-6; NO: Nitric oxide; MCP-1: Monocyte chemotactic protein-1; IL-8: Interleukin-8; 2-OG: 2-Oleoyl glycerol; 2-MAG: 2-Monoacylglycerol; LDL: Lipoprotein esterase; PPAR-a: Peroxisome proliferator activated receptor a; OGTT: Oral glucose tolerance test; HDL: High-density lipoprotein; PKA: Protein kinase A; CREB: CAMP response elementbinding protein; ERK1/2: Extracellular signal-regulated protein kinase 1 and 2; MEK1/2: Mitogen-activated protein kinase kinase1/2; ATP: Adenosine triphosphate; VDCC:Voltage-dependent calcium channel; ROS: Reactive oxygen species; NEFA: Non-esterified free fatty acid; VLDL: Very low-density lipoprotein; HFD: High-fat diet; LPL: Lipoprotein esterase; KCs: Kupffer cells; TNF-a: Tumor necrosis factor alpha; LPS: Lipopolysaccharides; IR: Insulin resistance; SCD-1: Stearoyl-coA desaturase -1; SREBP-1c: Sterol regulatory element-binding protein-1 c; HFD: High-fat diet; ALT: Alanine aminotransferase; AST: Aspartate aminotransferase; AMPK: AMP-activated protein kinase; GLP-1 1R: Glucagon-like peptide-1 receptor; LCFAs: Long-chain fatty acids; LPL: Lipoprotein esterase; KCs: Kupffer cells; IL-1 13: Interleukin-1 B; L-18: Interleukin-18; NF-kB: Nuclear factor-kappa B; LPS: Lipopolysaccharides; IR: Insulin resistance; LEA: Linoleoylethanolamide; PCI: Potential clinical importance; ECG: Electrocardiogram; MTT: Meal tolerance test; OGTT: Oral glucose tolerance test; $C_{\text {max }}$ : Maximum observed plasma drug concentration; $C_{\max , s 5}: C_{\max }$ at steady state; $T_{\max }:$ Time of maximum observed concentration; $T_{\max , s 5}$ $T_{\max }$ at steady state; AUC: Area under the plasma concentration time curve; AUC last: From time 0 to the last quantifiable concentration; M:P: Metabolite to parent; $\mathrm{AUC}_{0-24}$ : $\mathrm{AUC}$ from time 0 to $24 \mathrm{~h} ; \mathrm{AUC}_{\text {tau }}$ : $\mathrm{AUC}$ during the $24 \mathrm{~h}$ dosing interval; AccRatio: Accumulation ratio; TC: Total cholesterol; $\mathrm{AUC}_{0-3}$ : Area under the curve 0-3 h; FPG: PG and fasting plasma glucose; CLR: Renal clearance; iWMG: Incremental WMG; WMG: Weighted mean glucose; Vz/F: Apparent volume of distribution; CL/F: Apparent total systemic clearance after oral administration; $t 122$ : Apparent terminal elimination half-life.
\end{abstract}

Acknowledgements

Not applicable

Authors' contributions

$\mathrm{JZ}$ and $\mathrm{YZ}$ are responsible for the collection, collation and writing of the original manuscript, JP and $\mathrm{YH}$ are responsible for the revision and review of the manuscript. All authors read and approved the final manuscript. 


\section{Funding}

This work was supported by the National Natural Science Foundation of China (No. 81673750) and the National Natural Science Foundation of China (No. 81830119).

\section{Availability of data and materials}

Not applicable.

\section{Declarations}

\section{Ethics approval and consent to participate}

Not applicable.

\section{Consent for publication}

Not applicable.

\section{Competing interests}

The authors declare that they have no competing interests.

\section{Author details}

${ }^{1}$ Institute of Liver Diseases, Shuguang Hospital Affiliated To Shanghai, University of Traditional Chinese Medicine, 528, Zhangheng Road, Shanghai, China. ${ }^{2}$ Institute of Clinical Pharmacology, Shuguang Hospital Affiliated To Shanghai, University of Traditional Chinese Medicine, 528, Zhangheng Road, Shanghai, China. ${ }^{3}$ Key Laboratory of Liver and Kidney Diseases, Shanghai University of Traditional Chinese Medicine), Ministry of Education, 528 Zhangheng Road, Pudong District, Shanghai 201203, China. ${ }^{4}$ Shanghai Key Laboratory of Traditional Chinese Clinical Medicine, 528, Zhangheng Road, Shanghai, China.

Received: 7 June 2021 Accepted: 2 July 2021

Published online: 07 July 2021

\section{References}

1. Gong R, LV X, Liu F. MiRNA-17 encoded by the miR-17-92 cluster increases the potential for steatosis in hepatoma cells by targeting CYP7A1. Cell Mol Biol Lett. 2018;23:16.

2. Eslam M, Sarin SK, Wong VW, Fan JG, Kawaguchi T, Ahn SH, et al. The Asian Pacific Association for the Study of the Liver clinical practice guidelines for the diagnosis and management of metabolic associated fatty liver disease. Hepatol Int. 2020;14(6):889-919.

3. Zheng K, Fan J, Shi J, Wong V, Eslam M, George J, et al. From NAFLD to MAFLD: a "redefining" moment for fatty liver disease. Chinese med J-peking. 2020;133(19):2271-3.

4. Shiha G, Korenjak M, Eskridge W, Casanovas T, Velez-Moller P, Högström S, et al. Redefining fatty liver disease: an international patient perspective. Lancet Gastroenterol Hepatol. 2021;6(1):73-9.

5. Shiha G, Alswat K, Al Khatry M, Sharara A, Örmeci N, Waked I, et al. Nomenclature and definition of metabolicassociated fatty liver disease: a consensus from the Middle East and north Africa. Lancet Gastroenterol Hepatol. 2021;6(1):57-64.

6. Fouad Y, Elwakil R, Elsahhar M, Said E, Bazeed S, Ali Gomaa A, et al. The NAFLD-MAFLD debate: eminence vs evidence. Liver Int. 2021;41(2):255-60.

7. Yamamura S, Eslam M, Kawaguchi T, Tsutsumi T, Nakano D, Yoshinaga S, et al. MAFLD identifies patients with significant hepatic fibrosis better than NAFLD. Liver Int. 2020;40(12):3018-30.

8. Eslam M, Sarin SK, Wong WWS, Fan JG, Kawaguchi T, Ahn SH, et al. The Asian Pacific Association for the Study of the Liver clinical practice guidelines for the diagnosis and management of metabolic associated fatty liver disease. Hepatol Int. 2020;7:245.

9. Eslam M, Sanyal AJ, George J, Sanyal A, Neuschwander-Tetri B, Tiribelli C, et al. MAFLD: a consensus-driven proposed nomenclature for metabolic associated fatty liver disease. Gastroenterology. 2020;158(7):1999-2014.e1.

10. Mendez-Sanchez N, Arrese M, Gadano A, Oliveira CP, Fassio E, Arab JP, et al. The Latin American Association for the Study of the Liver (ALEH) position statement on the redefinition of fatty liver disease. Lancet Gastroenterol Hepatol. 2021;6(1):65-72.

11. Price NL, Ramírez CM, Fernández-Hernando C. Relevance of microRNA in metabolic diseases. Crit Rev Clin Lab Sci. 2014;51(6):305-20.

12. Golabi P, Paik J, Hwang J, Wang S, Lee H, Younossi Z. Prevalence and outcomes of non-alcoholic fatty liver disease (NAFLD) among Asian American adults in the United States. Liver Int. 2019;39(4):748-57.

13. Kikut-Ligaj D, Trzcielińska-Lorych J. How taste works: cells, receptors and gustatory perception. Cell Mol Biol Lett. 2015;20(5):699-716.

14. Hauser AS, Attwood MM, Rask-Andersen M, Schiöth HB, Gloriam DE. Trends in GPCR drug discovery: new agents, targets and indications. Nat Rev Drug Discov. 2017;16(12):829-42.

15. Yang JW, Kim HS, Choi Y-W, Kim Y-M, Kang KW. Therapeutic application of GPR1 19 ligands in metabolic disorders. Diabetes Obes Metab. 2018;20(2):257-69.

16. Hassing HA, Engelstoft MS, Sichlau RM, Madsen AN, Rehfeld JF, Pedersen J, et al. Oral 2-oleyl glyceryl ether improves glucose tolerance in mice through the GPR1 19 receptor. BioFactors. 2016;42(6):665-73.

17. Khound R, Taher J, Baker C, Adeli K, Su Q. GLP-1 elicits an intrinsic gut-liver metabolic signal to ameliorate dietinduced VLDL overproduction and insulin resistance. Arterioscler Thromb Vasc Biol. 2017;37(12):2252-9. 
18. Habib AM, Richards P, Rogers GJ, Reimann F, Gribble FM. Co-localisation and secretion of glucagon-like peptide 1 and peptide YY from primary cultured human L cells. Diabetologia. 2013;56(6):1413-6.

19. Cox H, Tough I, Woolston A, Zhang L, Nguyen A, Sainsbury A, et al. Peptide YY is critical for acylethanolamine receptor Gpr119-induced activation of gastrointestinal mucosal responses. Cell Metab. 2010;1 1(6):532-42.

20. Cani P, Possemiers S, Van de Wiele T, Guiot Y, Everard A, Rottier O, et al. Changes in gut microbiota control inflammation in obese mice through a mechanism involving GLP-2-driven improvement of gut permeability. Gut. 2009:58(8):1091-103.

21. Drucker D, Yusta B. Physiology and pharmacology of the enteroendocrine hormone glucagon-like peptide-2. Annu Rev Physiol. 2014;76:561-83.

22. Bulut K, Meier J, Ansorge N, Felderbauer P, Schmitz F, Hoffmann P, et al. Glucagon-like peptide 2 improves intestinal wound healing through induction of epithelial cell migration in vitro-evidence for a TGF-beta-mediated effect. Regul Pept. 2004;121(1-3):137-43.

23. Kouris G, Liu Q, Rossi H, Djuricin G, Gattuso P, Nathan C, et al. The effect of glucagon-like peptide 2 on intestinal permeability and bacterial translocation in acute necrotizing pancreatitis. Am J Surg. 2001;181(6):571-5.

24. Hsieh J, Longuet C, Maida A, Bahrami J, Xu E, Baker C, et al. Glucagon-like peptide-2 increases intestinal lipid absorption and chylomicron production via CD36. Gastroenterology. 2009;137(3):997-1005.

25. Zhang S, Ma Y, Li J, Ma J, Yu B, Xie X. Molecular matchmaking between the popular weight-loss herbHoodia gordoniiand GPR119, a potential drug target for metabolic disorder. Proc Natl Acad Sci. 2014;111(40):14571-6.

26. Psichas A, Larraufie PF, Goldspink DA, Gribble FM, Reimann F. Chylomicrons stimulate incretin secretion in mouse and human cells. Diabetologia. 2017;60(12):2475-85.

27. Zhou Y, Wang Y, Zhang L, Tang C, Feng B. Discovery and biological evaluation of novel G protein-coupled receptor 119 agonists for type 2 diabetes. Archiv der Pharmazie. 2019;352:4

28. Panaro B, Flock G, Campbell J, Beaudry J, Cao X, Drucker D. $\beta$-cell inactivation of unmasks incretin dependence of GPR119-mediated glucoregulation. Diabetes. 2017;66(6):1626-35.

29. Ismail S, Dubois-Vedrenne I, Laval M, Tikhonova I, D'Angelo R, Sanchez C, et al. Internalization and desensitization of the human glucose-dependent-insulinotropic receptor is affected by $\mathrm{N}$-terminal acetylation of the agonist. Mol Cell Endocrinol. 2015:414:202-15.

30. Liu Q, Gong Y, Li J, Zhang X, Gao G, Guo Y. Fine mapping of Smith-Fineman-Myers syndrome and exclusion of GPC3, GPCR2 MST4 and GLUD2 as candidate genes. Zhonghua Yi Xue Yi Chuan Xue Za Zhi. 2004;21 (3):198-202.

31. Davey J. G-protein-coupled receptors: new approaches to maximise the impact of GPCRS in drug discovery. Expert Opin Ther Targets. 2004;8(2):165-70.

32. Griffin G. Methods for identification of modulators of OSGPR116 activity. US7083933. 2006.

33. Bonini J, Borowsky B, Adham N, Boyle N, Thompson T. DNA encoding SNORF25 receptor. US 6221660. 2001.

34. Takeda S, Kadowaki S, Haga T, Takaesu H, Mitaku S. Identification of G protein-coupled receptor genes from the human genome sequence. FEBS Lett. 2002;520:97-101.

35. Fredriksson R, Höglund PJ, Gloriam DEI, Lagerström MC, Schiöth HB. Seven evolutionarily conserved human rhodopsin G protein-coupled receptors lacking close relatives. FEBS Lett. 2003;554(3):381-8.

36. Soga T, Ohishi T, Matsui T, Saito T, Matsumoto M, Takasaki J, et al. Lysophosphatidylcholine enhances glucosedependent insulin secretion via an orphan G-protein-coupled receptor. Biochem Biophys Res Commun. 2005;326(4):744-51.

37. Mo X, Yang Z, Tao Y. Targeting GPR1 19 for the potential treatment of type 2 diabetes mellitus. Prog Mol Biol Transl Sci. 2014;121:95-131.

38. Yang JW, Kim HS, Im JH, Kim JW, Jun DW, Lim SC, et al. GPR119: a promising target for nonalcoholic fatty liver disease. FASEB J. 2016:30(1):324-35.

39. Drzazga A, Sowińska A, Krzemińska A, Okruszek A, Paneth P, Koziołkiewicz M, et al. 2-OMe-lysophosphatidylcholine analogues are GPR1 19 ligands and activate insulin secretion from BTC-3 pancreatic cells: evaluation of structuredependent biological activity. Biochim Biophys Acta Mol Cell Biol Lipids. 2018;1863(1):91-103.

40. Overton H, Babbs A, Doel S, Fyfe M, Gardner L, Griffin G, et al. Deorphanization of a G protein-coupled receptor for oleoylethanolamide and its use in the discovery of small-molecule hypophagic agents. Cell Metab. 2006:3(3):167-75.

41. Lauren MC, Michael LM. Is GPR119 agonism an appropriate treatment modality for the safe amelioration of metabolic diseases? Expert Opin Investig Drugs. 2013;22(4):487-98.

42. Cornall LM, Mathai ML, Hryciw DH, Simcocks AC, O'Brien PE, Wentworth JM, et al. GPR1 19 regulates genetic markers of fatty acid oxidation in cultured skeletal muscle myotubes. Mol Cell Endocrinol. 2013;365(1):108-18.

43. Odori S, Hosoda K, Tomita T, Fujikura J, Kusakabe T, Kawaguchi Y, et al. GPR1 19 expression in normal human tissues and islet cell tumors: evidence for its islet-gastrointestinal distribution, expression in pancreatic beta and alpha cells, and involvement in islet function. Metabolism. 2013;62(1):70-8.

44. Ekberg JH, Hauge M. GPR119, a major enteroendocrine sensor of dietary triglyceride metabolites coacting in synergy with FFA1 (GPR40). Endocrinology. 2016;157:4561-9.

45. Hassing H, Fares $\mathrm{S}$, Larsen O, Pad H, Hauge M, Jones R, et al. Biased signaling of lipids and allosteric actions of synthetic molecules for GPR1 19. Biochem Pharmacol. 2016;119:66-75.

46. Nguyen CA, Akiba Y, Kaunitz JD. Recent advances in gut nutrient chemosensing. Curr Med Chem. 2012;19:28-34.

47. Talukdar S, Olefsky JM, Osborn O. Targeting GPR120 and other fatty acid-sensing GPCRs ameliorates insulin resistance and inflammatory diseases. Trends Pharmacol Sci. 2011;32(9):543-50.

48. Pertwee R, Howlett A, Abood M, Alexander S, Di Marzo V, Elphick M, et al. International union of basic and clinical pharmacology. LXXIX. Cannabinoid receptors and their ligands: beyond $\mathrm{CB}_{1}$ and $\mathrm{CB}_{2}$. Pharmacol Rev. 2010;62(4):588-631.

49. Moran BM, Flatt PR, McKillop AM. G protein-coupled receptors: signalling and regulation by lipid agonists for improved glucose homoeostasis. Acta Diabetol. 2016;53(2):177-88. 
50. Moran BM, Abdel-Wahab YHA, Flatt PR, McKillop AM. Activation of GPR1 19 by fatty acid agonists augments insulin release from clonal $\beta$-cells and isolated pancreatic islets and improves glucose tolerance in mice. Biol Chem. 2014;395(4):453-64.

51. Godlewski G, Offertáler L, Wagner J, Kunos G. Receptors for acylethanolamides-GPR55 and GPR119. Prostaglandins Other Lipid Mediat. 2009;89:105-11.

52. Kogure R, Toyama K, Hiyamuta S, Kojima I, Takeda S. 5-Hydroxy-eicosapentaenoic acid is an endogenous GPR1 19 agonist and enhances glucose-dependent insulin secretion. Biochem Biophys Res Commun. 2011;416(1-2):58-63.

53. Chu Z, Carroll C, Chen R, Alfonso J, Gutierrez V, He H, et al. N-oleoyldopamine enhances glucose homeostasis through the activation of GPR119. Mol Endocrinol. 2010;24(1):161-70.

54. Chu C, Huang S, De Petrocellis L, Bisogno T, Ewing S, Miller J, et al. N-oleoyldopamine, a novel endogenous capsaicin-like lipid that produces hyperalgesia. J Biol Chem. 2003;278(16):13633-9.

55. Hansen HS, Rosenkilde MM, Holst JJ, Schwartz TW. GPR1 19 as a fat sensor. Trends Pharmacol Sci. 2012;33(7):374-81.

56. Drzazga A, Kristinsson H, Sałaga M, Zatorski H, Koziołkiewicz M, Gendaszewska-Darmach E, et al. Lysophosphatidylcholine and its phosphorothioate analogues potentiate insulin secretion via GPR40 (FFAR1), GPR55 and GPR119 receptors in a different manner. Mol Cell Endocrinol. 2018;472:117-25.

57. Metz S. Ether-linked lysophospholipids initiate insulin secretion. Lysophospholipids may mediate effects of phospholipase A2 activation on hormone release. Diabetes. 1986;35(7):808-17.

58. Krautbauer S, Eisinger K, Wiest R, Liebisch G, Buechler C. Systemic saturated lysophosphatidylcholine is associated with hepatic function in patients with liver cirrhosis. Prostaglandins Other Lipid Mediat. 2016;124:27-33.

59. Hung N, Sok D, Kim M. Prevention of 1-palmitoyl lysophosphatidylcholine-induced inflammation by polyunsaturated acyl lysophosphatidylcholine. Inflamm Res. 2012;61(5):473-83.

60. Murugesan G, Sandhya Rani M, Gerber C, Mukhopadhyay C, Ransohoff R, Chisolm G, et al. Lysophosphatidylcholine regulates human microvascular endothelial cell expression of chemokines. J Mol Cell Cardiol. 2003;35(11):1375-84.

61. Hansen K, Rosenkilde M, Knop F, Wellner N, Diep T, Rehfeld J, et al. 2-Oleoyl glycerol is a GPR1 19 agonist and signals GLP-1 release in humans. J Clin Endocr Metab. 2011;96(9):E1409-17.

62. Kleberg K, Nielsen LL, Stuhr-Hansen N, Nielsen J, Hansen HS. Evaluation of the immediate vascular stability of lipoprotein lipase-generated 2-monoacylglycerol in mice. BioFactors. 2014;40(6):596-602.

63. Tough IR, Forbes S, Herzog H, Jones RM, Schwartz TW, Cox HM. Bidirectional GPR1 19 agonism requires peptide YY and glucose for activity in mouse and human colon mucosa. Endocrinology. 2018;159(4):1704-17.

64. Pavón F, Serrano A, Pérez-Valero V, Jagerovic N, Hernández-Folgado L, Bermúdez-Silva F, et al. Central versus peripheral antagonism of cannabinoid CB1 receptor in obesity: effects of LH-21, a peripherally acting neutral cannabinoid receptor antagonist, in Zucker rats. J Neuroendocrinol. 2008;7:116-23.

65. Thabuis C, Destaillats F, Landrier J, Tissot-Favre D, Martin J. Analysis of gene expression pattern reveals potential targets of dietary oleoylethanolamide in reducing body fat gain in C3H mice. J Nutr Biochem. 2010;21 (10):922-8.

66. Higuchi S, Ahmad T, Argueta D, Perez P, Zhao C, Schwartz G, et al. Bile acid composition regulates GPR119dependent intestinal lipid sensing and food intake regulation in mice. Gut. 2020;69(9):1620-8.

67. Flock G, Holland D, Seino Y, Drucker DJ. GPR1 19 regulates murine glucose homeostasis through incretin receptordependent and independent mechanisms. Endocrinology. 2011;152(2):374-83.

68. Chu Z, Jones R, He H, Carroll C, Gutierrez V, Lucman A, et al. A role for beta-cell-expressed G protein-coupled receptor 119 in glycemic control by enhancing glucose-dependent insulin release. Endocrinology. 2007;148(6):2601-9.

69. Hutch C, Trakimas D, Roelofs K, Pressler J, Sorrell J, Cota D, et al. Oea signaling pathways and the metabolic benefits of vertical sleeve gastrectomy. Ann Surg. 2020;271(3):509-18.

70. Semple G, Fioravanti B, Pereira G, Calderon I, Uy J, Choi K, et al. Discovery of the first potent and orally efficacious agonist of the orphan G-protein coupled receptor 119. J Med Chem. 2008;51(17):5172-5.

71. Chu Z-L, Carroll C, Alfonso J, Gutierrez V, He H, Lucman A, et al. A role for intestinal endocrine cell-expressed G protein-coupled receptor 119 in glycemic control by enhancing glucagon-like peptide-1 and glucose-dependent insulinotropic peptide release. Endocrinology. 2008;149(5):2038-47.

72. Marty V, Farokhnia M, Munier J, Mulpuri Y, Leggio L, Spigelman I. Long-acting glucagon-like peptide-1 receptor agonists suppress voluntary alcohol intake in male wistar rats. Front Neurosci. 2020;14:599646.

73. Gao J, Tian L, Weng G, O'Brien T, Luo J, Guo Z. Stimulating $\beta$-cell replication and improving islet graft function by AR231453, A GPR119 agonist. Transplant Proc. 2011;43(9):3217-20.

74. Ali S, Lamont B, Charron M, Drucker D. Dual elimination of the glucagon and GLP-1 receptors in mice reveals plasticity in the incretin axis. J Clin Invest. 2011;121(5):1917-29.

75. Panaro B, Flock G, Campbell J, Beaudry J, Cao X, Drucker D. Gpr119ß-cell inactivation of unmasks incretin dependence of GPR119-mediated glucoregulation. Diabetes. 2017;66(6):1626-35.

76. Semple G, Lehmann J, Wong A, Ren A, Bruce M, Shin Y, et al. Discovery of a second generation agonist of the orphan G-protein coupled receptor GPR1 19 with an improved profile. Bioorg Med Chem Lett. 2012;22(4):1750-5.

77. Katz L, Gambale J, Rothenberg P, Vanapalli S, Vaccaro N, Xi L, et al. Effects of JNJ-38431055, a novel GPR1 19 receptor agonist, in randomized, double-blind, placebo-controlled studies in subjects with type 2 diabetes. Diabetes Obes Metab. 2012;14(8):709-16.

78. Katz L, Gambale J, Rothenberg P, Vanapalli S, Vaccaro N, Xi L, et al. Pharmacokinetics, pharmacodynamics, safety, and tolerability of JNJ-38431055, a novel GPR1 19 receptor agonist and potential antidiabetes agent, in healthy male subjects. Clin Pharmacol Ther. 2011;90(5):685-92.

79. Ritter K, Buning C, Halland N, Pöverlein C, Schwink L. G Protein-Coupled Receptor 119 (GPR1 19) Agonists for the Treatment of Diabetes: Recent Progress and Prevailing Challenges. J Med Chem. 2016;59(8):3579-92.

80. Oshima H, Yoshida S, Ohishi T, Matsui T, Tanaka H, Yonetoku Y, et al. Novel GPR1 19 agonist AS1669058 potentiates insulin secretion from rat islets and has potent anti-diabetic effects in ICR and diabetic $\mathrm{db} / \mathrm{db}$ mice. Life Sci. 2013;92(2):167-73. 
81. Ning Y, O'Neill K, Lan H, Pang L, Shan L, Hawes B, et al. Endogenous and synthetic agonists of GPR1 19 differ in signalling pathways and their effects on insulin secretion in MIN6c4 insulinoma cells. Brit J Pharmacol. 2008;155(7):1056-65.

82. Fang $Y$, Xiong L, Hu J, Zhang S, Xie S, Tu L, et al. Synthesis and evaluation of novel fused pyrimidine derivatives as GPR119 agonists. Bioorg Chem. 2019;86:103-11.

83. Kim SR, Kim D-H, Park SH, Kim YS, Kim CH, Ha T-Y, et al. In Vivo Efficacy of HD0471953: A Novel GPR1 19 Agonist for the Treatment of Type 2 Diabetes Mellitus. J Diabetes Res. 2013;2013:1-6.

84. Wacker D, Wang Y, Broekema M, Rossi K, O'Connor S, Hong Z, et al. Discovery of 5-chloro-4-((1-(5-chloropyrimidin2-yl)piperidin-4-yl)oxy)-1-(2-fluoro-4-(methylsulfonyl)phenyl)pyridin-2(1H)-one (BMS-903452), an antidiabetic clinical candidate targeting GPR1 19. J Med Chem. 2014;57(18):7499-508.

85. Campbell J, Drucker D. Pharmacology, physiology, and mechanisms of incretin hormone action. Cell Metab. 2013;17(6):819-37.

86. Arifin S, Paternoster S, Carlessi R, Casari I, Ekberg J, Maffucci T, et al. Oleoyl-lysophosphatidylinositol enhances glucagon-like peptide-1 secretion from enteroendocrine L-cells through GPR119. Biochim Biophys Acta Mol Cell Biol Lipids. 2018;1863(9):1132-41.

87. Yin X, Zheng F, Pan Q, Zhang S, Yu D, Xu Z, et al. Glucose fluctuation increased hepatocyte apoptosis under lipotoxicity and the involvement of mitochondrial permeability transition opening. J Mol Endocrinol. 2015:55(3):169-81.

88. Faitova J, Krekac D, Hrstka R, Vojtesek B. Endoplasmic reticulum stress and apoptosis. Cell Mol Biol Lett. 2006;11(4):488-505.

89. Zhao J, Hu Y, Peng J. Targeting programmed cell death in metabolic dysfunction-associated fatty liver disease (MAFLD): a promising new therapy. Cell Mol Biol Lett. 2021;26(1):17.

90. Huan Y, Jiang Q, Li G, Bai G, Zhou T, Liu S, et al. The dual DPP4 inhibitor and GPR1 19 agonist HBKO01 regulates glycemic control and beta cell function ex and in vivo. Sci Rep. 2017;7(1).

91. Yoshida S, Tanaka H, Oshima H, Yamazaki T, Yonetoku Y, Ohishi T, et al. AS1907417, a novel GPR1 19 agonist, as an insulinotropic and $\beta$-cell preservative agent for the treatment of type 2 diabetes. Biochem Biophys Res Commun. 2010;400(4):745-51.

92. Cvijanovic N, Isaacs N, Rayner C, Feinle-Bisset C, Young R, Little T. Lipid stimulation of fatty acid sensors in the human duodenum: relationship with gastrointestinal hormones. BMI and diet Int J Obes (Lond). 2017:41 (2):233-9.

93. Koh G, Suh K, Chon S, Oh S, Woo J, Kim S, et al. Elevated cAMP level attenuates 2-deoxy-d-ribose-induced oxidative damage in pancreatic beta-cells. Arch Biochem Biophys. 2005;438(1):70-9.

94. Kwon G, Pappan K, Marshall C, Schaffer J, McDaniel M. cAMP Dose-dependently prevents palmitate-induced apoptosis by both protein kinase A- and CAMP-guanine nucleotide exchange factor-dependent pathways in beta-cells. J Biol Chem. 2004;279(10):8938-45.

95. Ding X, Saxena NK, Lin S, Gupta N, Anania FA. Exendin-4, a glucagon-like protein-1 (GLP-1) receptor agonist, reverses hepatic steatosis inob/ob mice. Hepatology. 2006;43(1):173-81.

96. Kim M, Kim TH, Cheyong Y, Chae YA, Jung IH, Lee K, et al. Long-term Treatment of DA-1241, a Novel GPR119 Agonist,Improved Glucose Control via Preserved Beta Cell Mass in a ProgressiveDiabetic Mice Model. ADA Forecast. 2015;280-LB.

97. Bahirat UA, Shenoy RR, Talwar R, Goel RN, Nemmani KVS. Co-administration of APD668, a G protein-coupled receptor 119 agonist and linagliptin, a DPPIV inhibitor, prevents progression of steatohepatitis in mice fed on a high trans-fat diet. Biochem Biophys Res Commun. 2018;495(2):1608-13.

98. Kern M, Klöting N, Niessen H, Thomas L, Stiller D, Mark M, et al. Linagliptin improves insulin sensitivity and hepatic steatosis in diet-induced obesity. Plos One. 2012;7(6):e38744.

99. Shirakawa J, Fujii H, Ohnuma K, Sato K, Ito Y, Kaji M, et al. Diet-induced adipose tissue inflammation and liver steatosis are prevented by DPP-4 inhibition in diabetic mice. Diabetes. 2011;60(4):1246-57.

100. Bahirat UA, Shenoy RR, Goel RN, Nemmani KVS. APD668, a G protein-coupled receptor 119 agonist improves fat tolerance and attenuates fatty liver in high-trans fat diet induced steatohepatitis model in C57BL/6 mice. Eur J Pharmacol. 2017;801:35-45.

101. Gupta NA, Mells J, Dunham RM, Grakoui A, Handy J, Saxena NK, et al. Glucagon-like peptide-1 receptor is present on human hepatocytes and has a direct role in decreasing hepatic steatosis in vitro by modulating elements of the insulin signaling pathway. Hepatology. 2010;51(5):1584-92.

102. Hu Y-W, Yang J-Y, Ma X, Chen Z-P, Hu Y-R, Zhao J-Y, et al. A lincRNA-DYNLRB2-2/GPR1 19/GLP-1R/ABCA1dependent signal transduction pathway is essential for the regulation of cholesterol homeostasis. J Lipid Res. 2014;55(4):681-97.

103. Szabo G, CsakT. Inflammasomes in liver diseases. J Hepatol. 2012;57(3):642-54.

104. Grill M, Högenauer C, Blesl A, Haybaeck J, Golob-Schwarzl N, Ferreirós N, et al. Members of the endocannabinoid system are distinctly regulated in inflammatory bowel disease and colorectal cancer. Sci Rep. 2019;9(1):2358.

105. Lee YS, Park MS, Choung JS, Kim SS, Oh HH, Choi CS, et al. Glucagon-like peptide-1 inhibits adipose tissue macrophage infiltration and inflammation in an obese mouse model of diabetes. Diabetologia. 2012;55(9):2456-68.

106. Chen X, Huang Q, Feng J, Xiao Z, Zhang X, Zhao L. GLP-1 alleviates NLRP3 inflammasome-dependent inflammation in perivascular adipose tissue by inhibiting the NF-KB signalling pathway. J Int Med Res. 2021;49(2):300060521992981.

107. Koppel N, Balskus E. Exploring and Understanding the Biochemical Diversity of the Human Microbiota. Cell Chem Biol. 2016;23(1):18-30.

108. Cani PD, Everard A, Duparc T. Gut microbiota, enteroendocrine functions and metabolism. Curr Opin Pharmacol. 2013;13(6):935-40.

109. Chepurny OG, Holz GG, Roe MW, Leech CA. GPR119 Agonist AS1269574 Activates TRPA1 Cation Channels to Stimulate GLP-1 Secretion. Mol Endocrinol. 2016;30(6):614-29.

110. Cohen LJ, Esterhazy D, Kim S-H, Lemetre C, Aguilar RR, Gordon EA, et al. Commensal bacteria make GPCR ligands that mimic human signalling molecules. Nature. 2017;549(7670):48-53. 
111. Fitriakusumah Y, Lesmana C, Bastian W, Jasirwan C, Hasan I, Simadibrata M, et al. The role of Small Intestinal Bacterial Overgrowth (SIBO) in Non-alcoholic Fatty Liver Disease (NAFLD) patients evaluated using Controlled Attenuation Parameter (CAP) Transient Elastography (TE): a tertiary referral center experience. BMC Gastroenterol. 2019;19(1):43.

112. Augustyn M, Grys I, Kukla M. Small intestinal bacterial overgrowth and nonalcoholic fatty liver disease. Clin Exp Hepatol. 2019;5(1):1-10.

113. Kapil S, Duseja A, Sharma B, Singla B, Chakraborti A, Das A, et al. Small intestinal bacterial overgrowth and toll-like receptor signaling in patients with non-alcoholic fatty liver disease. J Gastroen Hepatol. 2016;31 (1):213-21.

114. Lund ML, Egerod KL, Engelstoft MS, Dmytriyeva O, Theodorsson E, Patel BA, et al. Enterochromaffin 5-HT cells—a major target for GLP-1 and gut microbial metabolites. Mol Metab. 2018;11:70-83.

115. Margolis KG, Vittorio J, Talavera M, Gluck K, Li Z, luga A, et al. Enteric serotonin and oxytocin: endogenous regulation of severity in a murine model of necrotizing enterocolitis. Am J Physiol Gastrointest Liver Physiol. 2017;313(5):G386-98.

116. Png C, Lindén S, Gilshenan K, Zoetendal E, McSweeney C, Sly L, et al. Mucolytic bacteria with increased prevalence in IBD mucosa augment in vitro utilization of mucin by other bacteria. Am J Gastroenterol. 2010;105(11):2420-8.

117. Santacruz A, Collado M, García-Valdés L, Segura M, Martín-Lagos J, Anjos T, et al. Gut microbiota composition is associated with body weight, weight gain and biochemical parameters in pregnant women. $\mathrm{Br} J$ Nutr. 2010;104(1):83-92.

118. Everard A, Belzer C, Geurts L, Ouwerkerk J, Druart C, Bindels L, et al. Cross-talk between Akkermansia muciniphila and intestinal epithelium controls diet-induced obesity. Proc Natl Acad Sci U S A. 2013;110(22):9066-71.

119. Deal W. Metabolex and Sanofi-Aventis partner on GPCR agonists for type 2 diabetes. Nat Rev Drug Discov. 2010:9(9):670.

120. Gendaszewska-Darmach E, Drzazga A, Koziołkiewicz M. Targeting GPCRs activated by fatty acid-derived lipids in type 2 diabetes. Trends Mol Med. 2019;25(10):915-29.

121. Mandøe MJ, Hansen KB, Hartmann B, Rehfeld JF, Holst JJ, Hansen HS. The 2-monoacylglycerol moiety of dietary fat appears to be responsible for the fat-induced release of GLP-1 in humans. Am J Clin Nutr. 2015;102(3):548-55.

122. Fyfe M, Mccormack J, Overton H, Procter M, CR. PSN821: A novel oral GPR1 19 agonist for the treatment of type 2 diabetes producing substantial glucose lowering and weight loss in rats. In American Diabetes Association 68th Annual Scientific SessionsSan Francisco, CA. 2008:Abstract 297-OR.

123. Negoro K, Yonetoku Y, Maruyama T, Yoshida S, Takeuchi M, Ohta M. Synthesis and structure-activity relationship of 4-amino-2-phenylpyrimidine derivatives as a series of novel GPR119 agonists. Bioorg Med Chem. 2012;20(7):2369-75.

124. Shah U, Kowalski T. GPR1 19 agonists for the potential treatment of type 2 diabetes and related metabolic disorders. Vitam Horm. 2010;84:415-48.

125. Kang S-U. GPR1 19 agonists: a promising approach for T2DM treatment? A SWOT analysis of GPR119. Drug Discov Today. 2013;18(23-24):1309-15.

126. Murakami T, Fujimoto H, Fujita N, Hamamatsu K, Matsumoto K, Inagaki N. Noninvasive evaluation of GPR1 19 agonist effects on $\beta$-cell mass in diabetic male mice using $111 \mathrm{ln}$-exendin-4 SPECT/CT. Endocrinology. 2019;160(12):2959-68.

127. Watada H, Shiramoto M, Irie S, Terauchi Y, Yamada Y, Shiosakai K, et al. G protein-coupled receptor 119 agonist DS-8500a effects on pancreatic $\beta$-cells in Japanese type 2 diabetes mellitus patients. J Diabetes Investig. 2019;10(1):84-93.

128. Kato M, Furuie H, Kamiyama E, Shiosakai K, Yoshihara K, Taguchi T. Safety and pharmacokinetics of DS-8500a, a Novel GPR1 19 agonist, after multiple oral doses in healthy Japanese males. Clin Drug Investig. 2018;38(6):519-25.

129. Yamada Y, Terauchi Y, Watada H, Nakatsuka Y, Shiosakai K, Washio T, et al. Efficacy and safety of GPR1 19 agonist DS8500a in Japanese patients with type 2 diabetes: a randomized, double-blind, placebo-controlled, 12-week study. Adv Ther. 2018;35(3):367-81.

130. Inagaki N, Chou H, Tsukiyama S, Washio T, Shiosakai K, Nakatsuka Y, et al. Glucose-lowering effects and safety of DS-8500a, a G protein-coupled receptor 119 agonist, in Japanese patients with type 2 diabetes: results of a randomized, double-blind, placebo-controlled, parallel-group, multicenter, phase II study. BMJ Open Diabetes Res Care. 2017;5(1):424

131. Matsumoto K, Yoshitomi T, Ishimoto Y, Tanaka N, Takahashi K, Watanabe A, et al. DS-8500a, an orally available $\mathrm{G}$ protein-coupled receptor 119 agonist, upregulates glucagon-like peptide- 1 and enhances glucosedependent insulin secretion and improves glucose homeostasis in type 2 diabetic rats. J Pharmacol Exp Ther. 2018:367(3):509-17.

132. Terauchi Y, Yamada Y, Watada H, Nakatsuka Y, Shiosakai K, Washio T, et al. Efficacy and safety of the G proteincoupled receptor 119 agonist DS-8500a in Japanese type 2 diabetes mellitus patients with inadequate glycemic control on sitagliptin: a phase 2 randomized placebo-controlled study. J Diabetes Investig. 2018;9(6):1333-41.

133. Hothersall JD, Bussey CE, Brown AJ, Scott JS, Dale I, Rawlins P. Sustained wash-resistant receptor activation responses of GPR119 agonists. Eur J Pharmacol. 2015;762:430-42.

134. Kim H, Yoon H, Park J, Che X, Jin X, Choi J. G protein-coupled receptor 119 is involved in RANKL-induced osteoclast differentiation and fusion. J Cell Physiol. 2019:234(7):11490-9.

135. Ohishi T, Yoshida S. The therapeutic potential of GPR1 19 agonists for type 2 diabetes. Expert Opin Investig Drugs. 2012;21(3):321-8

136. Yoshida S, Ohishi T, Matsui T, Tanaka H, Oshima H, Yonetoku Y, et al. Novel GPR119 agonist AS1535907 contributes to first-phase insulin secretion in rat perfused pancreas and diabetic db/db mice. Biochem Biophys Res Commun. 2010;402(2):280-5.

137. Yoshida S, Ohishi T, Matsui T, Tanaka H, Oshima H, Yonetoku Y, et al. The role of small molecule GPR119 agonist, AS1535907, in glucose-stimulated insulin secretion and pancreatic $\beta$-cell function. Diabetes Obes Metab. 2011;13(1):34-41. 
138. Ansarullah E, Free C, Christopherson J, Chen Q, Gao J, Liu C, et al. Activation of GPR1 19 Stimulates Human $\beta$-Cell Replication and Neogenesis in Humanized Mice with Functional Human Islets. J Diabetes Res. 2016;2016:1620821.

139. Fyfe MCT, McCormack JG, Overton HA, Procter MJ, Reynet C. GPR119 agonists as potential new oral agents for the treatment of type 2 diabetes and obesity. Expert Opin Drug Discov. 2008;3(4):403-13.

140. Kim S, Kim D, Kim Y, Ha T, Yang J, Park S, et al. HD047703, a new promising anti-diabetic drug candidate. Vivo Preclinical Studies Biomol Ther. 2014;22(5):400-5.

141. Ha T, Kim Y, Kim C, Choi H, Yang J, Park S, et al. Novel GPR1 19 agonist HD0471042 attenuated type 2 diabetes mellitus. Arch Pharm Res. 2014;37(5):671-8.

142. Tyurenkov IN, Kurkin DV, Bakulin DA, Volotova EV, Morkovin El, Chafeev MA, et al. Chemistry and Hypoglycemic Activity of GPR1 19 Agonist ZB-16. Front Endocrinol (Lausanne). 2018;9:543.

143. Harada K, Mizukami J, Watanabe T, Mori G, Ubukata M, Suwa K, et al. Lead generation and optimization of novel GPR119 agonists with a spirocyclic cyclohexane structure. Bioorg Med Chem Lett. 2019;29(3):373-9.

\section{Publisher's Note}

Springer Nature remains neutral with regard to jurisdictional claims in published maps and institutional affiliations.

- fast, convenient online submission

- thorough peer review by experienced researchers in your field

- rapid publication on acceptance

- support for research data, including large and complex data types

- gold Open Access which fosters wider collaboration and increased citations

- maximum visibility for your research: over 100M website views per year

At BMC, research is always in progress.

Learn more biomedcentral.com/submissions 